Who is not Poor?

By Lant Pritchett

Abstract
Poverty reduction is now, and quite properly should remain, the primary objective of the World Bank.
But, when the World Bank dreams of a world free of poverty-what should it be dreaming? I argue in
this essay that the dream should be a bold one, that treats citizens of all nations equally in defining
poverty, and that sets a high standard for what eliminating poverty will mean for human well-being.
I purpose a new standard for global income poverty for the World Bank's use. This poverty line is the
weighted average of the poverty lines declared by its shareholders, where the declared poverty line is
no lower than the country uses for its own citizens. I show this will imply a poverty line of around
U.S.\$15 a day in current purchasing power adjusted currency units-about ten times higher than the
existing standard.




\title{
Who is not Poor? Proposing A Higher International Standard for Poverty
}

\author{
Lant Pritchett \\ Kennedy School of Government, Harvard University \\ and
}

Center for Global Development

CGD Working Paper \#33 ${ }^{1}$

November 2003

${ }^{1}$ An essay in honor of Poverty Day, October 17, 2003. 


\section{Executive summary}

Poverty day is a good day to celebrate the commitment to the reduction of global poverty. Poverty reduction is now, and quite properly should remain, the primary objective of the World Bank. But, when the World Bank dreams of a world free of poverty - what should it be dreaming? I argue in this essay that the dream should be a bold one, that treats citizens of all nations equally in defining poverty, and that sets a high standard for what eliminating poverty will mean for human well-being.

I have a very simple proposal - to introduce a new standard for global income poverty for the World Bank's use. This poverty line is the weighted average of the poverty lines declared by its shareholders, where the declared poverty line is no lower than the country uses for its own citizens. I show this will imply a poverty line of around 15P\$/day in current purchasing power adjusted currency units $\left(\mathrm{P}^{2}\right)$ - about ten times higher than the existing standard. This higher poverty line, if used with consideration for the depth and intensity of poverty, and used together with other indicators of deprivation in well-being (health, education, water) and with measures of household and social vulnerability can be a solid foundation for the World Bank's poverty reduction agenda.

The existing low poverty lines would continue, but to avoid confusion I would propose renaming the "1P\$/day" 3 as "destitution" and the "2P\$/day" standard "extreme poverty." The World Bank can track progress in all three internationally comparable standards of income poverty: global poverty, extreme poverty, and destitution. Each country would continue to use their own poverty lines, which would likely fall between the "destitution" and "global" standards, for national purposes.

While there are many legitimate measures of poverty besides income poverty, and while there are many technical issues in computing income poverty once a poverty line is established, there is a quite simple question, simple because the alternatives are so stark. The simple question is: "for the definition of an income poverty line should the World Bank use exclusively low poverty lines or should they also include a high poverty line (like $\$ 15 /$ day)?" The answer is also simple - "the use of a high poverty line is justifiable, more consistent with international fairness, and is a better foundation for the World Bank's organizational mission of poverty reduction."

While the essay will make many points, my arguments boil down to three basic points.

First, because poverty is a social construct each country should be free to set its own definitions of poverty and its own poverty line for defining income poverty. But for setting a common, international, standard for income poverty - for what constitutes "unacceptable" depri-

\footnotetext{
2 All references to "dollars" should be understood as adjusted for purchasing power in the relevant country and are denoted P\$ and if those are for an earlier year I will use the year as well to indicate this may have been affected by inflation.

${ }^{3}$ Of course the $1 \$$ /day standard has changed with inflation and $1 \$$ /day in 1985 terms (which was the original calculation for the $1990 \mathrm{WDR}$ ) is now, if updated by US price inflation to 2000 about $\$ 1.60$ a day. While if one updates the \$1.08 P\$/1993 standard (also called "dollar a day") to 2000 by the US CPI the standard one only gets P\$1.28/day. Sala-i-Martin (2002) updates from 1985 to 1996 (for comparability with the Penn Tables and gets $1.45 \mathrm{P} \$ 1996$. So the "one dollar a day" standard as originally set is now roughly $\$ 1.50 /$ day.
} 
vation in the human condition or "inadequate" income in a globalized world -it seems grossly unfair that a person is "poor" if born in one country and yet is "not poor" with a level of real income ten times lower if born in another. That is, while India might set a poverty line that is attuned to its capabilities and circumstances and the USA another, for international comparisons choosing the lower line implies that what is "unacceptable" deprivation for a US resident is acceptable for another human being simply because of their residence. So, either we say there are no poor at all in industrialized countries — or we acknowledge that persons in all countries with the same level of well-being as the poor in industrialized countries should also be counted as "global poor."

Second, while in principle one can imagine a rationale for a social objective in which gains in income of individuals above some threshold count for nothing, I argue that the low poverty lines set that threshold too low. For instance, one recent, not unreasonable ${ }^{4}$, study (Sala-iMartin 2002) of world income poverty rates found that at the conventional \$1/day standard only $6 \%$ percent of the world's population was "poor" and hence 94 percent were not income poor (these are lower than the standard estimates, as reported in the WDR 2002 for instance, for a variety of reasons he explains). If "poverty reduction" is the taken as the World Bank's objective and the standard measure is used to define "poverty" then this is telling 95 percent of the world's population that their diligent efforts to improve their material well-being and increase their incomes count for nothing in the World Bank's stated objectives. By these same estimates even by the $2 \$$ /day standard only 18 percent of the population was poor so even the World Bank's most "generous" standard for international poverty implies that four-fifths of the world's population are not income poor.

\begin{tabular}{|l|l|}
\hline \multicolumn{2}{|l|}{ Table ES: Estimates of income poverty } \\
by current standards \\
\hline $\begin{array}{l}\text { 1\$/day } \\
(=1.45 \mathrm{P} \$ 1996)\end{array}$ & $6.7 \%$ \\
\hline $\begin{array}{l}2 \$ / \text { day } \\
(=2.90 \mathrm{P} \$ 1996)\end{array}$ & $18.6 \%$ \\
\hline Not Poor & $81.4 \%$ \\
\hline \multicolumn{2}{|l|}{ Source: Sala-i-Martin } \\
\hline
\end{tabular}

The basic problem with the low poverty lines is not that the people how are "poor" by the low standards not in fact poor-they are $^{5}$. But the point that is missed completely is that by dividing up into two catego-

\footnotetext{
${ }^{4}$ That is, there are many complications with estimating global poverty-does one use household survey based estimates of consumption expenditures or estimates from national accounts? Deaton (2003) reviews the evidence of these points (and addresses the puzzle of why they their growth rates have been so different recently) and the relative merits of different approaches. At this stage my only argument is that combining national accounts estimates of incomes/consumption with household survey based estimates of the distribution is not an unreasonable procedure. ${ }^{5}$ These are quite different from the numbers reported in the WDR 2000/2001 based on the work of Ravallion and Chen for reasons explained in Sala-i-Martin as the use of income versus consumption data and whether the figures refer to the poor in the world (Sala-i-Martin) or the poor in the third world (Ravallion and Chen). Again, this is not to prefer one set of estimates over another as reasonable people can disagree about whether to use consumption expenditures or national income to calculate poverty rates, but the impact of raising the poverty line is similar for both.
} 
ries above and below a threshold one also has to assert that people above that line are not poor. While someone with less than $1 \$$ /day or $2 \$$ /day is truly poor - can anyone say with any confidence that households with per person consumption of $2.01 \$$ /day are not poor? With low poverty lines the World Bank's estimates of poverty in quite poor countries are very low, by the $1 \$$ /day standard in Cote d'Iviore only 12.3 percent of the population are poor, only 11.3 percent of Bolivians are poor, only 15.2 percent of Indonesians, only 6.6 percent of Sri Lankans. Does anyone really believe the statement that " 94 percent of Sri Lankans are not poor"?

It seems as if, in defining a poverty line, there was so much concern about mistakenly saying someone was poor when they were not that the implications of the error of saying someone is not poor when they are were forgotten. All of the statements about the numbers of poor can only be understood as a lower bound--as saying reasonably "there are at least X billion poor" but not "there are only X billion poor"

This problem with asserting the converse goes deep-if "poverty" is "unacceptable" deprivation this implies the deprivation of the "non-poor' is acceptable. As we I will show below, these penurious poverty lines are grossly inconsistent with indicators of physical well-being. Low poverty lines imply that in many countries 50 percent of the "non-poor" have children who are malnourished, that the infant mortality rate of the "non-poor" is over 100 per 1000 , that 50 percent of the children of the "non-poor" do not finish primary education. I argue international standards do not, and cannot, find these levels of human deprivation are acceptable.

Third, a poverty reduction objective with a high poverty line can support the broad array of activities that constitute a development agenda. If however, "poverty reduction" is narrowly construed as the income poverty as defined by low poverty lines-which is the risk from exclusive use of low poverty lines--then this risks transforming the World Bank from the broad development agency of its name into a narrow "charity" agency. Most people engaged in the process of development on all sides are convinced that a broad array of activities are needed-from attacking corruption and improving governance to developing infrastructure to protecting the environment to improving the quality of basic schooling, to promoting the policies and institutions that accelerate broad based growth. But none of these things could be justified with the 1 $\mathrm{P} \$ 85 /$ day poverty lines even in countries as poor as Sri Lanka because if only 6 percent are poor then only one sixteenth of any uniform improvement would benefit "the poor."

Income poverty (with intensity weights) with a high poverty line combined with specific targets for other indicators of well-being (consistent with a multi-dimensional approach to defining poverty) and attention to risks and vulnerability is a solid foundation for international efforts to improve human well being. Poverty reduction can then truly be the objective. But using a low poverty line exclusively for measuring income/consumption poverty is unjustified, unproductive, and unnecessary.

\section{Introduction}

I want to emphasize up front that this is an essay, not a research paper or monograph reporting research results. Even more specifically this is an essay that hopes to be a persuasive essay. This is the form appropriate to the topic since choosing a poverty line to define income 
poverty is not a technical question which research into facts could resolve, even in principle ${ }^{6}$. The definition of poverty is a social question about which one can make a case. This is a case based on facts, like the level of the poverty line in the industrialized countries and the level of malnutrition of the "non-poor" in poor countries, but ultimately, the question is "what do 'we' agree to mean when 'we' in the broad international community say 'income poverty' in the global context?"

As an essay this is informed by more than just the existing academic literature on poverty but also by the existing practice within international institutions. Moreover, since I have made these points orally in conversations and seminars and presentations over the years, I will also draw on reactions and conversations and rejoinders from colleagues and friends to not only make the case, but also answer objections.

In keeping with the essay format, I would like to make a personal note on background that, on poverty issues, I am a heretic, not an atheist. That is, this is not an "outside" critique--I have been, and will remain, a part of the "poverty" work both in research and in "operations" within the World Bank. It is precisely this operational experience of facing actual policy challenges in real countries has convinced me that the "low poverty lines" approach is inadequatebut has also convinced me there is a very simple solution.

\section{How should the World Bank determine a "global" poverty line?}

Poverty is a social construct and is a complex, multi-dimensional phenomena ${ }^{7}$. If we begin with some general definition of poverty as "any unacceptable deprivation in human wellbeing" it is obvious that moving from a definition to a concrete measure requires specifying what are the relevant dimensions of "well-being" and what level of deprivation is "unacceptable."

\footnotetext{
${ }^{6}$ When approaching the issue from an economic approach, I find the most fruitful way to think about the poverty line is by using the notion of an expenditure function so that the poverty line is the expenditures necessary to achieve a given level of well-being (utility) given the prices faced and the characteristics of the household: $P L=e\left(p, H X, U^{P}\right)$. While this helps keep poverty lines comparable across regions and household characteristics, there is not "technical" way to fix the overall poverty line which depends on the social convention about the level of utility $\mathrm{U}^{\mathrm{p}}$ used to define "poverty."

7 This accounts for the fact that the word has so many different, contested, meanings and so many different measures - but the fact that the concept of poverty, like the concepts of "freedom" and "justice" and "democracy"--has many different legitimate meanings makes the concept of poverty no less important.
} 


\section{I.A) The World Bank should define and calculate "global income poverty" as a weighted average of the poverty lines of its shareholders}

Since poverty is a social construct we need to begin with a social group for which the definition of poverty will be relevant. While each country will have its own poverty line (if it chooses that approach to poverty) what should the international community - and the World Bank in particular--mean by "income poverty" ?

Since the vast majority of the international assistance for funding for the fight against global poverty comes from the industrialized economies it seems reasonable to ask-what do

\begin{tabular}{|l|r|r|}
\hline \multicolumn{3}{|l|}{$\begin{array}{l}\text { Table 1: Industrial country shares in World Bank } \\
\text { capital and in development assistance }\end{array}$} \\
\hline Country & $\begin{array}{l}\text { Share of } \\
\text { World Bank } \\
\text { subscriptions }\end{array}$ & $\begin{array}{l}\text { Share of Devel- } \\
\text { opment Assis- } \\
\text { tance Commit- } \\
\text { tee ODA (1999) }\end{array}$ \\
\hline United States & 16.86 & $16.2 \%$ \\
\hline Japan & 8.08 & $27.2 \%$ \\
\hline Germany & 4.61 & $9.8 \%$ \\
\hline France & 4.42 & $10.0 \%$ \\
\hline United Kingdom & 4.42 & $6.0 \%$ \\
\hline Canada & 2.85 & $3.0 \%$ \\
\hline Italy & 2.85 & $3.2 \%$ \\
\hline Netherlands & 2.26 & $5.6 \%$ \\
\hline Belgium & 1.84 & $1.3 \%$ \\
\hline Other industrial & 9.98 & $17.0 \%$ \\
\hline Total industrial & 58.17 & $99.4 \%$ \\
\hline
\end{tabular}
they mean by poverty? The industrialized countries constitute almost 60 percent of the voting shares in the organization, so it is not unreasonable to propose that what they mean by poverty should have some significant bearing on what the organization means by poverty. For instance, the USA is the largest single shareholder of the World Bank and exerts considerable influence in the organization and strongly supports the poverty reduction efforts of the World Bank. Presumably the USA means by poverty the same thing for its citizens and for other citizens of the planet, as one can hardly imagine that the USA wishes to take either the position that none of its citizens are "poor" or that what it means

by poverty depends on the color of people's skin or other accidents of birth. This is not of course to say the USA is not willing to spend more, perhaps dramatically more, to alleviate poverty among US citizens and residents than among citizens of other countries but it still should mean the same thing when it defines poverty. The same should be true of other countries-whatever standard of deprivation they think is unacceptable for their citizens, however they define it, should be unacceptable for all other human beings.

My first proposal is to allow each shareholder of the Bank declare its desired standard for global poverty, with the proviso that this standard can be no lower, but could be higher, than the standard they use for their own citizens. Any country in the world could make the case the international system should endow their citizens have the same right to aspire to a high level of material well being as those of the now rich countries. What is the international political justification for the position that if a person's income goes from $\$ 3,000$ to $\$ 4,000$ in the USA this is enor-

\footnotetext{
${ }^{8}$ I want to focus on defining income poverty not because that is the only, or even most important, poverty objective - but it is the international measure of poverty that receives the most attention. Also, I will argue exactly the same approach of defining thresholds based on industrialized country minimal standards could be used for other "poverty" indicators.
} 
mously important and reduces poverty but if (equivalently measured) income goes from $\$ 700$ to $\$ 800$ in Mexico this does not count at all for poverty reduction ${ }^{9}$.

The United States has a very clearly and officially defined poverty line that is used in determining eligibility for a wide variety of social programs ${ }^{10}$. In the United States the official

\begin{tabular}{|r|r|r|}
\hline \multicolumn{2}{|l|}{ Table 2: USA Poverty Lines, 2000} \\
\hline $\begin{array}{l}\text { Family } \\
\text { size }\end{array}$ & \$/year & \multicolumn{2}{|l|}{$\$$ day } \\
\hline 1 & $\$ 8,350$ & $\$ 22.9$ \\
\hline 2 & $\$ 11,250$ & $\$ 15.4$ \\
\hline 3 & $\$ 14,150$ & $\$ 12.9$ \\
\hline 4 & $\$ 17,050$ & $\$ 11.7$ \\
\hline Average & & $\$ 15.7$ \\
\hline
\end{tabular}

poverty lines vary by household size and composition (since it is assumed that there are substantial "economies of scale" within a household). For a single individual the poverty line in 2000 was $\$ 8,350$ per year or $22.9 \$$ /day while each additional individual adds $\$ 2,900$ to the poverty line so that for an urban family of 4 the poverty line is $11.7 \$$ /day. The US poverty line is an absolute line and has not been updated to raise the real value of the poverty basket or to reflect Source: HSS Poverty Guidelines for contiguous 48 states current consumption, so, as we will see, the US poverty line is by a substantial amount the lowest relative to income of any OECD country.

\begin{tabular}{|c|c|}
\hline \multicolumn{2}{|c|}{$\begin{array}{l}\text { Table 3: After tax low income } \\
\text { cutoffs, Canada, 1996, by city } \\
\text { size }\end{array}$} \\
\hline Household size & $2000 \mathrm{P \$} /$ day \\
\hline 1 & $\$ 27.38$ \\
\hline 2 & $\$ 16.70$ \\
\hline 3 & $\$ 14.08$ \\
\hline 4 & $\$ 13.16$ \\
\hline Average & $\$ 17.83$ \\
\hline \multicolumn{2}{|c|}{$\begin{array}{l}\text { From C\$ to US\$, adjusted for } \\
\text { PPP, and for US CPI inflation. }\end{array}$} \\
\hline
\end{tabular}

Canada does not have an official poverty line, but does report "low income cutoffs" (LICO) that are popularly referred to as a poverty line. Again, these display considerable economies of scale (so that the per day amount is lower for larger households) but the average across the household sizes, in $2000 \mathrm{P}$, is almost $\$ 18$ per day.

\footnotetext{
${ }^{9}$ Not to mention (or, to only mention in a footnote) the fact that if a Mexican citizen who has income of $\$ 2,000$ willingly and voluntarily crosses the border in order to make $\$ 3,000$ (with no ex post regrets) then world income has gone up, world welfare has gone up (assuming no negative spillovers on either side of the border) and yet poverty measured at national standards has also gone up.

${ }^{10}$ Although never, to my knowledge in a strictly binary,yes/no below/above the poverty line. Usually benefits are scaled according to the households position relative to the poverty line with benefits phasing about substantially above the poverty line. [
} 


\begin{tabular}{|l|l|}
\hline $\begin{array}{l}\text { Table 4: 50\% of median equivalent } \\
\text { household income in OECD countries } \\
\text { in P\$ per day }\end{array}$ \\
\hline \multicolumn{2}{|l|}{} \\
\hline Sweden & $\$ 2000 \mathrm{P} \$$ \\
\hline UK & $\$ 28.48$ \\
\hline Finland & $\$ 29.10$ \\
\hline Australia & $\$ 32.52$ \\
\hline France & $\$ 32.60$ \\
\hline Germany & $\$ 32.60$ \\
\hline Netherlands & $\$ 32.76$ \\
\hline Denmark & $\$ 33.30$ \\
\hline Belgium & $\$ 35.93$ \\
\hline Canada & $\$ 36.51$ \\
\hline Norway & $\$ 37.99$ \\
\hline Switzerland & $\$ 40.50$ \\
\hline USA & $\$ 41.16$ \\
\hline Average (unweighted) & $\$ 33.95$ \\
\hline Source: Smeeding and &
\end{tabular}

Source: Smeeding and Rainwater 2002, table 3 , adjusted for US CPI inflation
Most OECD countries do not have an official poverty line but it is very common to use a threshold of $50 \%$ of median equivalent income to define poverty. For instance, the Human Development Reports use this standard for the OECD countries. This is explicitly a relative standard for these countries but that does not prevent us from using their standard as an absolute global standard. As can be seem from table 4 these poverty lines would fall between P\$28 to and P\$41. As noted above, these are much more generous than the official US line.

\begin{tabular}{|c|c|c|}
\hline Country & & \\
\hline AUS & & ר2 20א \\
\hline BEL & & 42L.2L \\
\hline DEL & $\$ 21.03$ & $\$ 19.91$ \\
\hline CAN & $\$ 14.01$ & $\$ 13.06$ \\
\hline DNK & $\$ 23.39$ & $\$ 20.99$ \\
\hline ESP & $\$ 9.87$ & $\$ 9.92$ \\
\hline FRA & & $\$ 16.68$ \\
\hline GRC & $\$ 10.83$ & $\$ 10.55$ \\
\hline IRL & $\$ 17.27$ & $\$ 21.11$ \\
\hline JPN & $\$ 12.76$ & $\$ 11.61$ \\
\hline NLD & $\$ 21.05$ & $\$ 20.02$ \\
\hline NZL & $\$ 15.85$ & $\$ 13.81$ \\
\hline PRT & $\$ 8.11$ & $\$ 7.81$ \\
\hline USA & $\$ 11.84$ & $\$ 12.28$ \\
\hline Average & $\$ 15.16$ & $\$ 15.38$ \\
\hline
\end{tabular}

An alternative for gauging industrial country standards for "poverty" is to examine minimum wages. As minimum wages are often set based on some notion of the minimum amount at which a worker can sustain him/herself and their family. A recent data base collected information on official minimum wages around the world for a period in the early or late 1990s. If one transforms the annual earnings of the minimum wage in the OECD countries into an income per calendar day and divides by 2 (on the assumption a minimum wage worker can support one other person) then the average minimum wage is P\$15/day. Note that if we assume the minimum wage is expected to only support to worker him/herself the average is \$30/day-roughly the "half median household earnings" standard.

The evidence is overwhelming that the industrialized countries, who together constitute some 60 percent of the subscriptions of the World Bank (and hence collectively control the institution) consider that income levels below $\$ 15 /$ day per person 
for their citizens is "poverty" - an unacceptable human deprivation in wellbeing $^{11}$. I will use this figure to illustrate the implications of a "high" poverty line principally because it is a nice round number and because it is almost exactly an order of magnitude - ten timeshigher than the current standard.

\begin{tabular}{|l|l|l|}
\hline \multicolumn{3}{|l|}{ Table 6: Proposed new thresholds for the different } \\
international definitions of poverty
\end{tabular}

\section{I.B) Objections to raising the global poverty line}

This section addresses four objections to a high poverty line: (a) that they are not as well theoretically or "scientifically" grounded as low poverty lines, (b) that it is inappropriate to use one country's poverty line for another country, (c) that it would include people who are not "really" poor, (d) that increasing incomes above a very low level is not a legitimate social or international objective. I argue that high poverty lines are consistent with any alternative plausible method for saying who is not poor.

\section{Q: But aren't the existing poverty lines nutritionally determined or based on economics?}

\section{A: No, not nutrition, no, not economics.}

Not nutritionally determined. One myth is that the poverty lines are not an arbitrary social convention about which there can be non-technical arguments, but rather are solidly based on scientifically based nutritional requirements. Many people think that the low poverty lines are based on what it "costs" to reach a nutritionally adequate diet and that determines the poverty line. But people who actually work with poverty lines know better - while low poverty lines are related to nutritional requirements these do not determine the poverty line. This is discussed in detail in appendix 1, but the main point is that in any given country exactly the same nutritional requirements could imply poverty rates of 5 or 50 percent depending on social conventions about the basket of food consumed to reach the nutritional requirements.

Not grounded in economics. A second widespread misconception is that "poverty" analysis is grounded in economics. But, even though it has been mostly economists who have promoted it poverty lines, and in particular low poverty lines, poverty lines have no widely accepted grounding in standard economics or wide acceptance by economists (appendix 2$)^{12}$. In conversations with users of low poverty lines within the World Bank they agree fully that poverty lines are inconsistent with standard welfare economics-but argues that it is economics that

\footnotetext{
${ }^{11}$ While in actual practice, when the World Bank adopts a standard for "global poverty" that is the weighted average of shareholder poverty lines, each shareholder country could designate the line it proposed, with the proviso that the line could be higher, but not lower, than the standard they set for their own citizens.

${ }^{12}$ This is putting it mildly. I have never met a single economist who honestly believed that "reduction of income poverty with a low poverty line" was sound as a sole (or even primary) objective of policy making (except in perhaps very very poor countries where a low poverty line still incorporates most of the population) while many do believe that something like an inequality averse social welfare function is a (reasonably) sound foundation for normative discussions of policy. Most economists who do write about "poverty" with low poverty lines do so only because it is "relevant" for reasons beyond their control.
} 
should be changed ${ }^{13}$. I am pleased that we agree on that key point: that "poverty" analysis is not grounded in existing economics.

The key difference between a poverty analysis that uses a threshold to define poverty and conventional social welfare economics is not that income gains to poorer households receive more "weight" in poverty analysis--this is not in fact generally true as a standard social welfare function with inequality aversion puts more weight on gains to the poorest than do many standard poverty measures (illustrated in figure 1 as "EDEI"). The key difference between most "poverty" analysis and standard economics is that gains to those above the poverty threshold receive zero weight. In a standard social welfare function gains to those with higher incomes receive diminishing, but positive weight. In contrast, with poverty analysis gains to those above the poverty line get zero weight.

Figure 1: Sensitivity of various poverty measures to gains in income of various percentiles of the income distribution...

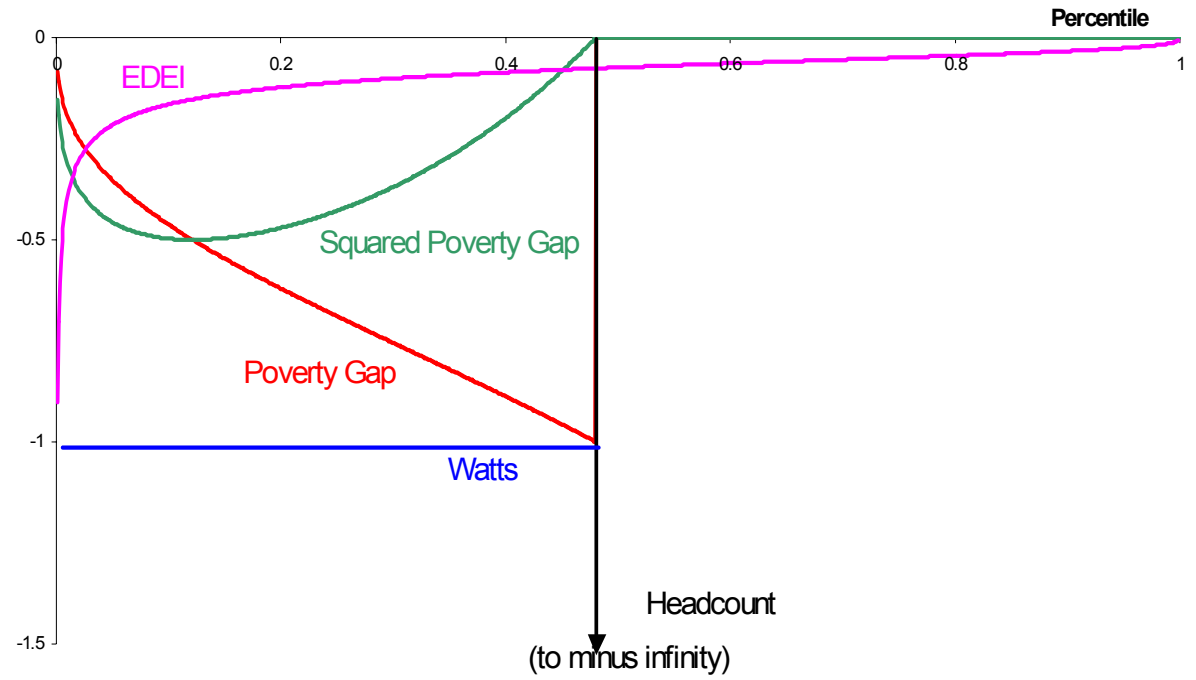

Source: Kraay 2003

This is a place to explain what I mean by "intensity weights." Even if one defines a poverty line this does not determine a measure of "poverty" as one has to specify how to weight the gains to people below the poverty line. That is, no one takes seriously "poverty reduction" as an objective with "poverty" defined as headcount. This is because the only reduction in headcount poverty comes as someone moves across the poverty line and hence income gains to those with incomes substantially below the poverty lines counts for nothing. Figure 1 shows the elasticity of poverty reduction with respect to increases in income of persons in the $p^{\text {th }}$ percentile of the income distribution. "Headcount poverty" is unresponsive to gains to those below the line

${ }^{13}$ Email communication with the author. Of course, just because poverty lines are not economics does not imply that there is not perhaps some other "moral philosophy" grounding (see appendix below) or pragmatic justification for low poverty lines. 
(hence is zero) then goes to minus infinity at the poverty line and returns to zero.

Other poverty measures of the Foster Greer Thoerbecke class can be defined by a parameter that records the "intensity" of a given depth below the poverty line so that the "poverty gap" is where this parameter equals 1 , and the "squared poverty gap" when the parameter equals 2. Figure 1 shows the elasticity of these poverty measures as well. Even thought the squared poverty gap does eliminate the "kink" at the poverty line that implies a discontinuous change in how income gains are valued, it too falls to zero across the poverty line threshold. The Watts poverty measure is defined differently as has constant elasticity of poverty reduction to an improvement in income of the $p^{\text {th }}$ percentile right up to the poverty line. But all of them go to zero at the poverty line so that people just below the poverty line count infinitely more in the proposed social objective function of "poverty" than people just below the poverty line.

I am agnostic with respect to the appropriate "intensity weight" but with either low or high poverty lines "poverty reduction" as an objective with a given empirical measure of poverty only makes sense with some intensity weights as literally targeting the headcount poverty rate never makes sense. The use of intensity weights does address the problem with the high poverty lines that there would be little reduction in "headcount" poverty until people reached very high levels compared to current income. But any "intensity weighted" poverty measure would decrease with any broad based increase per capita income.

That poverty analysis is not conventional economics or does not have rigorous economic grounding is not a compelling argument against it. In many ways "poverty" measures are like the Human Development Index (HDI) or indicators of "unsatisfied basic needs" which are difficult to give a rigorous economic foundation but which many find useful shortcuts for advocacy and "rough and ready" policy targets. I am a pragmatist, not a purist. I am not arguing against the use of poverty analysis. I am arguing against the use combination of poverty analysis combined with the exclusive use of low poverty lines. That is, since if the World Bank says "poverty reduction" is its objective and consistently and exclusively uses "low poverty line" when measuring poverty this combination (which I will call PRO-LPL) implies that income gains to households above a very low threshold don't matter at all in fulfilling the objective.

If poverty analysis is used to give some rough and ready policy target then the poverty line should be such that the gains to income of those just at the poverty line count for very near zero in the overall social objective. The rest of this essay argues that this is emphatically not true of low poverty lines - gains to well-being near the low poverty lines are tremendously important—but is defensible for high poverty lines. standard?

\section{Q: Isn't it inappropriate to use one set of countries poverty lines as an international}

A: No, that is exactly how the low poverty lines are set. The difference between the low and high lines is just which countries are used to set the international standard.

High poverty lines by the method I propose are the exact methodological equivalent of the existing method for setting the internationally comparable low poverty lines. As described in 
the WDR 2000/2001 on poverty the low poverty line is set as the median of the poverty lines of the ten poorest countries. That is, there is no science, no economics, just a convention to define poverty as what the poorest countries define to be poverty (and then, just to emphasize how that this is an arbitrary social convention as a standard, also double it) ${ }^{14}$. The high poverty line can be justified by exactly the same method - let us adopt as the international standard for "global poverty" the poverty lines of the industrialized countries.

Why choose and use exclusively for defining global income poverty the lowest of country poverty lines? The argument in its favor is that we can be absolutely sure than anyone below the poverty line set for the poorest countries in the world is truly poor. But this seems in fact like a perfect definition for "destitution" not "poverty" because a good definition needs to imply the converse as well. So, while someone who has an income above the poverty line for India is likely not "destitute" but to say that, because someone is not poor by the standard of India they are not "poor" seems not right (in ways made clear below).

There is an analogy with statistics of "type I" and "type II" errors and there are conventions about the levels of "type I" error (e.g. 1\%, 5\%, 10\% levels of "statistical significance") that are purposively conservative. But in this case, there is no compelling case for why a poverty line should be set "conservatively" so as to be sure to avoid "falsely" saying that someone is poor when they are not. So using two extreme lines has some appeal. One can be sure that someone below the lowest line is truly poor-but there is a good chance that someone above that line is poor. By the same token, one can be reasonably sure that someone above the higher standard for "global poverty" is not poor, but it may well also include as poor some who are "not poor."

Q: But if we accept a P\$15/day standard won't nearly everyone in many poor countries be "poor" by this standard?

A: Yes, and this is a defensible answer as even most of the people in the upper end of the income distribution in poor countries are less well off by every indicator of physical well-being that the poor in rich countries. So, unless one is willing to assert that there are no poor in rich countries (e.g. that the level of material well-being of the very bottom of the income distribution in industrialized countries is not low enough to be "poverty") then this makes the standard reasonable.

There is a truly pernicious myth that people in poor countries are not "really" poor. This is sustained by anecdotes like "I knew an Indian family once and they were much better off than I ever was..." or "When I went to country X the people I met were doing well..." There are billions of people in poor countries and of course there are well-off people in poor countries —after all, the richest one tenth of one percent is still a million people. But to extrapolate this very far

\footnotetext{
${ }^{14}$ That is, when I say something is "arbitrary" or a "social convention" I do not mean this to mean it is irrational or capricious, I simply mean that there are always assumptions about setting the poverty line about which reasonable people can disagree and for which there is no way of resolving through an objective (or even inter-subjectively valid) method. However, while the $1 \$$ /day standard or nutritionally based national poverty lines have some procedure the $2 \$$ /day standard is literally 2 times higher. Why 2 ? Why not 1.86 ? Why not $e$ ? Why not $\pi / 2$ ? The very fact that both standards can be used side by side shows that poverty lines are entirely a social convention - and I argue $\$ 15 /$ day is a more reasonable social convention.
} 
down the income distribution is like judging social conditions in America by visiting only one apartment building on the upper East Side of Manhattan.

Since the implication of my proposed revision of the poverty line is that more than 80 percent of the population of most poor countries will be "global poor" I want to emphasize that the purchasing power adjusted measures of real incomes are in fact consistent with non-money indicators of well being ${ }^{15}$. People with incomes lower than the $15 \$$ /day in poor countries have physical indicators of well-being consistent with having lower standards of living than the poor in industrialized countries ${ }^{16}$.

Prices are much cheaper in poor countries and that the same money income at official exchanges rates will buy more. But all of the income comparisons I will make are already adjusted for the fact that goods are cheaper and once this adjustment is made the numbers are reasonably comparable. Four widely used physical indicators of well-being or indicators of household income - child health, malnutrition, education, food share - all indicate that the richest quintile of households in poor countries are much worse off by these indicators than the "poor" in rich countries.

Start with infant mortality. In the poorest neighborhoods in Canada in 1996 mortality was 6.4 (Wilkins, et. al 2002). In the most "deprived" areas of Great Britain infant mortality was a little over 8 . A not unreasonable conjecture would be that average infant mortality among the "poor" in most OECD countries is 10 per ' 000 or less ${ }^{17}$. Therefore, one would expect if the "rich" in poor countries were really better off than the poor in rich countries we would expect infant mortality would be lower than 10. In fact, in a recent study of the inequalities in consumption expenditures and in health status the infant mortality of the richest quintile in all of the countries examined was much higher than 10-from substantially higher in Brazil to four to six times as high in Nepal, Nicaragua, and Cote'd'Ivoire up to even ten times as high in Pakistan. So if the global income poverty calculations imply that more than 80 percent of the population of any of these countries this it would be consistent with infant mortality suggesting the richest 20 percent is worse off than the poor in rich countries ${ }^{18}$.

\footnotetext{
15 A calculation that Dani Rodrik has made is whether the "rich" (defined as the top 10 percent)in a poor country (bottom 10 percent of median incomes) have higher income than the "poor" (defined as the bottom 10 percent) in a rich country. The PPP income of a "rich" individual in a "poor" country by his calculation is P\$2,800 while the income of a "poor" individual in a "rich" country is P\$ 8640 (\$23/day). This section shows these PPP adjusted money income calculations are broadly consistent with the differences in physical indicators of well-being.

${ }^{16}$ I emphasize "consistent with" because, no matter what indicator one chooses there are difficult problems in using that indicator to compare "well-being" across individuals or groups. The purpose here is entirely heuristic - to show that there is no evidence that the PPP adjustments end up grossly understating real incomes in poor countries-but this is not compelling evidence they are "correct."

${ }^{17}$ To follow up on the famous anecdote, infant mortality in Washington DC among those classified by the census as "black" is 16.9 .

${ }^{18}$ Even presumably well meaning anecdotes like that life expectancy at birth for African Americans in Washington is lower than in parts of India can mislead as these extremes made striking and memorable anecdotes precisely because they are such glaring exceptions to the general rule - a point not always obvious to the casual listener..
} 
Figure 2: Infant mortality of the richest quintile (by consumption expenditures) is far above that of the poor in industrial countries...

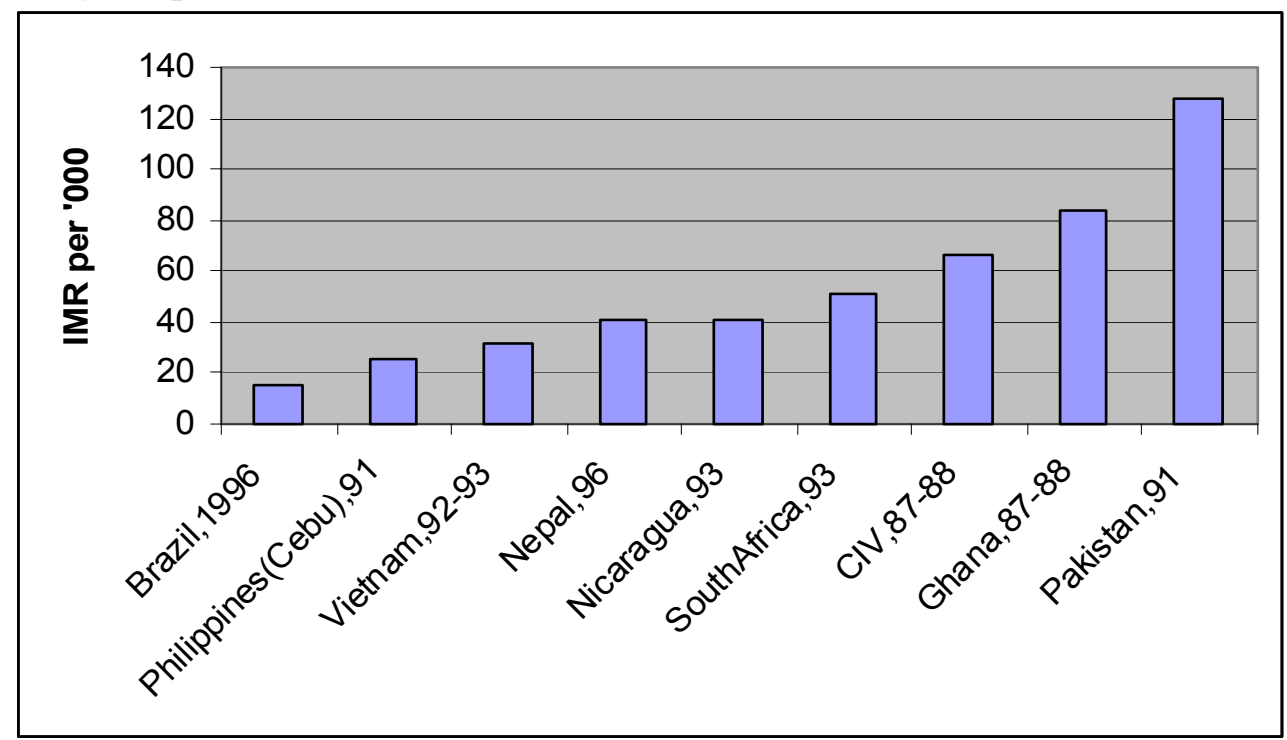

Source: HNP country indicators

Figure 3 shows the prevalence of "stunting"- children more than two standard deviations below the US norms among the richest quintile (using data on an index of household assets). More than three in ten children of the "rich" in India, in Pakistan, in Nigeria, in Nepal shows signs of chronic malnutrition.

Figure 3: Malnutrition in many developing countries affects as many of a third of children in the richest quintiles (by an asset index)

(fraction of children "stunted" height for age less than 2 s.d. less than norms)

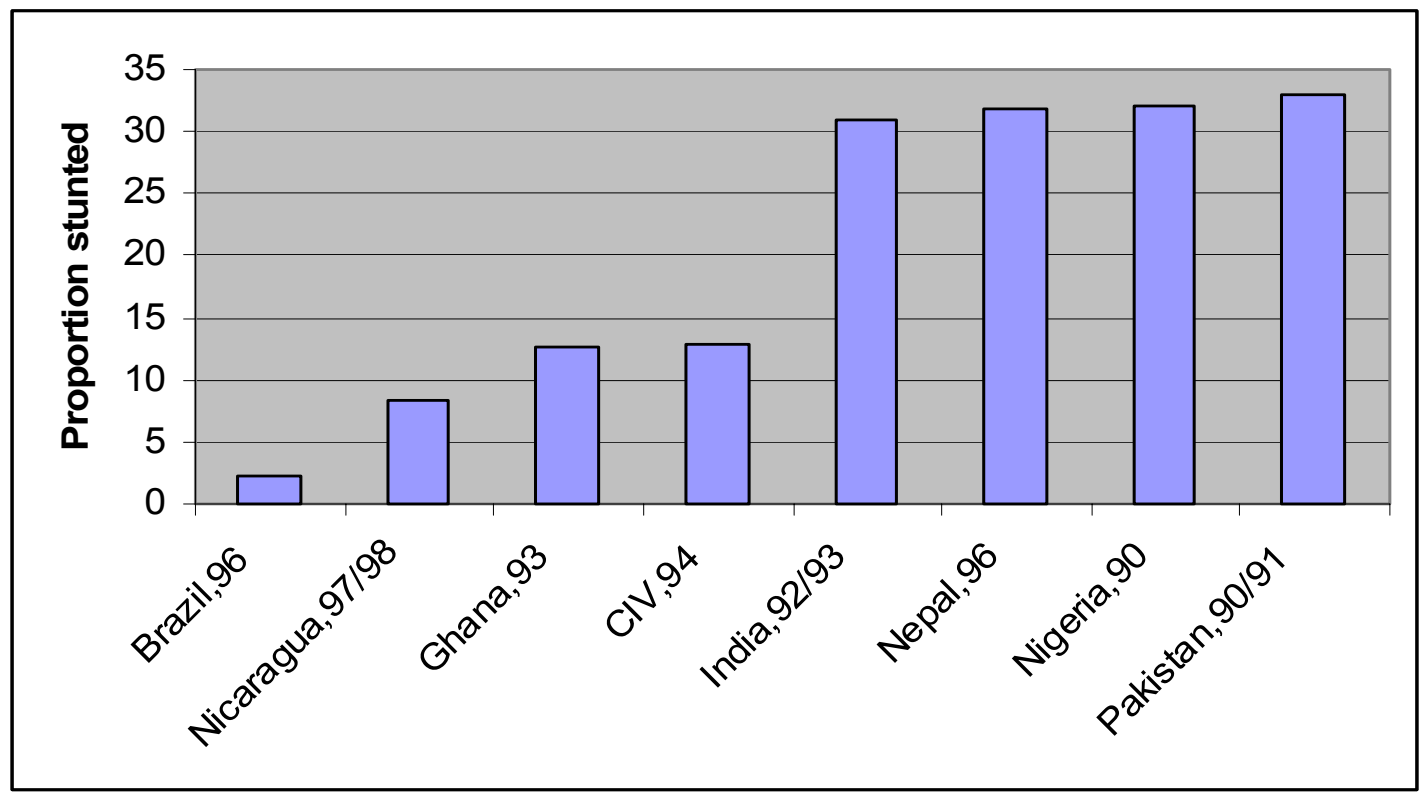

Source: From HNP country indicators. 
In industrialized countries completion of basic education is nearly universal, even among the very poor. In contrast, even among the richest quintile in poorer countries between a quarter and three quarters of children do not complete even $9^{\text {th }}$ grade (figure 4 ).

Figure 4: Fraction of richest quintile not completing grade 9

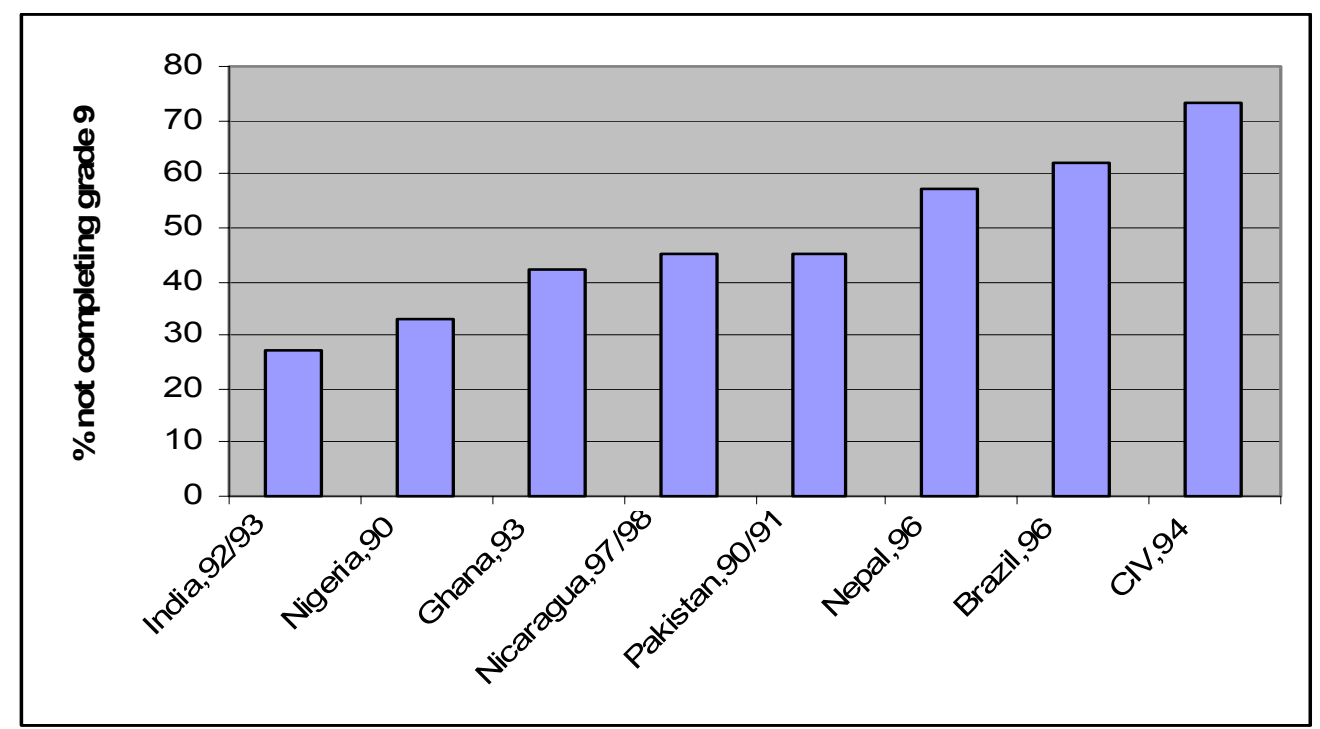

Source: World Bank web site on educational attainment

The share of expenditures on food is often used as an indicator of well-being because of the well-established downward sloping relationship between income and the share of expenditures on food (Engle curve). As Besley and Burgess (2003) point out, the food share of the "dollar a day" poor in 1993-94 India was 73 percent. The food share of the poorest quintile group in the United Sates in 2001 was 17 percent. While the food share falls with rising income, the food share of the highest fractile group (95-100\%) in rural India was $42 \%$ and of the highest urban group was $34.5 \%$. Figure 5 presents the food share of the richest group (fractile indicated) in household surveys from the 1970s ${ }^{19}$. While the richest few percent in Brazil are lower than the USA even the upper tails of the income distribution have food shares of 30-40 percent. As with the other indicators of well-being, food shares of expenditures are higher for the "richer" in poor countries than the poor in rich countries.

\footnotetext{
${ }^{19}$ Sorry about the old numbers, but it is what I had available. The point has not changed over time as the Engle curve is remarkably steady.
} 
Figure 5: Food expenditures as a share of total consumption expenditures of the upper-most income group (US bottom quintile food share 17 percent)

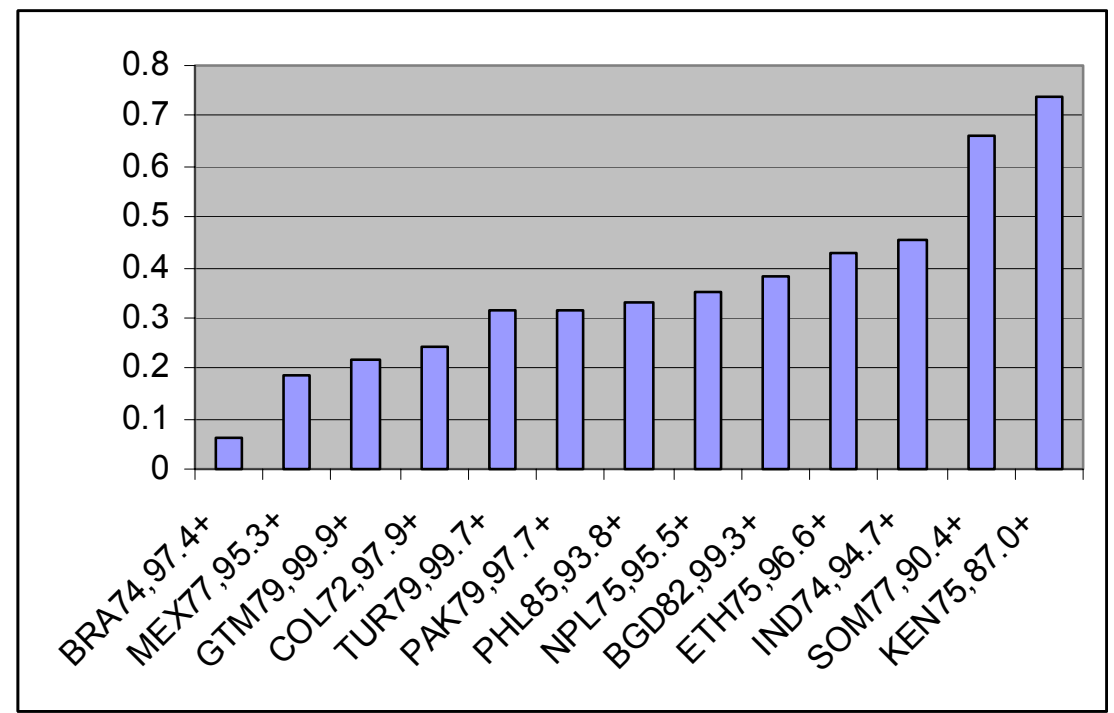

Source: Author, from FAO 1981.

So the first objection to a high poverty line--that people in the upper part of the income distribution that would be classified as poor in poor countries by a common standard, even using purchasing power adjusted dollars, are not "really" as poor as the poor in rich countries is belied by the every single physical indicator or proxy for well-being. Well into the upper tails of the income distribution people in poorer countries have children who are more likely to die, more likely to be mal-nourished, more likely to not complete basic education, than the poor in rich countries.

Moreover, evaluating these same physical indicators of well being at the current low poverty lines shows that the "non-poor" have physical well-being indicators that are far too low to be an internationally "acceptable" deprivation in well-being. For instance, the $1 \$$ /day standard implies that only 12 percent of Ivoirians are poor-but in the group between the 20 and 40 percentiles - the "non-poor" the infant mortality rate is nearly 100 per thousand. In Nepal 1\$/day poverty is very high — reaching 37.7 percent - but among the "non-poor" by that standard (those in the $40-60^{\text {th }}$ percentiles) infant mortality is 100 and stunting affects half of the children. 


\begin{tabular}{|c|c|c|c|c|c|c|}
\hline \multirow[t]{2}{*}{$\begin{array}{l}\text { Country } \\
\text { (year of poverty } \\
\text { estimate, year of } \\
\text { indicators) }\end{array}$} & \multirow[t]{2}{*}{$\begin{array}{l}1 \$ / \text { day } \\
\text { head } \\
\text { count }\end{array}$} & \multicolumn{2}{|c|}{$\begin{array}{l}\text { Physical indicators of } \\
\text { well-being of the next } \\
\text { asset quintile that is } \\
\text { "non-poor" }\end{array}$} & \multirow[t]{2}{*}{$\begin{array}{l}2 \$ / \text { day } \\
\text { headcount }\end{array}$} & \multicolumn{2}{|c|}{$\begin{array}{l}\text { Physical indicators of } \\
\text { well-being of the asset } \\
\text { quintile that is "non- } \\
\text { poor" }\end{array}$} \\
\hline & & IMR & $\begin{array}{l}\text { Mal- } \\
\text { Nutrition } \\
\text { (stunting) }\end{array}$ & & IMR & $\begin{array}{l}\text { Mal- } \\
\text { nutrition }\end{array}$ \\
\hline $\begin{array}{l}\text { Brazil } \\
(97,96)\end{array}$ & 5.1 & $\begin{array}{l}46.7 \\
(\mathrm{qII})\end{array}$ & $\begin{array}{l}8.7 \\
\text { (qII) }\end{array}$ & 17.4 & $\begin{array}{l}46.7 \\
\text { (qII) }\end{array}$ & $\begin{array}{l}8.7 \\
\text { (qII) }\end{array}$ \\
\hline $\begin{array}{l}\text { Cote d'Ivoire } \\
(95,94)\end{array}$ & 12.3 & $\begin{array}{l}97.3 \\
(\mathrm{qII})\end{array}$ & $\begin{array}{l}28.5 \\
\text { (qII) }\end{array}$ & 49.4 & $\begin{array}{l}78.8 \\
(\mathrm{qIII})\end{array}$ & $\begin{array}{l}17.3 \\
(\mathrm{qIII})\end{array}$ \\
\hline $\begin{array}{l}\text { Nepal } \\
(95,96)\end{array}$ & 37.7 & $\begin{array}{l}103 \\
\text { (qIII) }\end{array}$ & $\begin{array}{l}48.1 \\
(\mathrm{qIII})\end{array}$ & 82.5 & $\begin{array}{l}63.9 \\
(\mathrm{qV})\end{array}$ & $\begin{array}{l}31.8 \\
(\mathrm{qV})\end{array}$ \\
\hline $\begin{array}{l}\text { Pakistan } \\
(96,91)\end{array}$ & 31.0 & $\begin{array}{l}109.3 \\
\text { (qIII) }\end{array}$ & $\begin{array}{l}52.4 \\
(\mathrm{qIII})\end{array}$ & 84.7 & $\begin{array}{l}62.5 \\
(q V)\end{array}$ & $\begin{array}{l}32.9 \\
(\mathrm{qV})\end{array}$ \\
\hline
\end{tabular}

Even if one uses the $2 \$$ /day standard the same problem remains that the assertion that the "non-poor" have acceptable levels of well-being cannot be defended. As the "non-poor" in all instances have infant mortality rates near or above 50. Defending even a $2 \$ /$ day as a standard at which one can take the "non-poor" label seriously requires the assertion that an infant mortality rate five times as high as that of the poor in industrialized countries is acceptable deprivation-because after all, these children are born in poor countries.

Alternative Method 1 for establishing "poverty lines": Income at which any widely used indicator physical well-being reach "acceptable" levels, that is the levels of the poorest in rich countries.

An alternative to using industrial country poverty lines as a standard for global poverty lines would be to establish some thresholds for indicators of physical well-being - suppose that infant mortality be no higher than 15 or that malnutrition be no higher than 5 or that all children complete primary schooling - and define the income poverty line as the level of income at which, on average, this goal was attained. One could then run either run a regression to establish the level in each country of the level of income at which it is "predicted" that these indicators would be reached. Alternatively, one could use international regressions to establish this is a cross national context — what is the level of income at which, on average, across countries, acceptable levels of physical well being are reached?

Figure $6 a, b, c$ illustrate this method for education. Using data on educational attainment of children and the percentiles of per capita expenditures of the child's household one can regress the probability that a child completes grade 5 (a minimalist definition of "primary") on the households rank (using a flexible functional form). Then one can ask: at what percentile of the distribution of expenditures is the predicted probability of completing primary education 90 percent? This method would justify very high poverty rates for every country examined. In Brazil 
(in 1996) this would imply a poverty line that would make 95 percent of households poor. In Nepal essentially 100 percent of households would be poor. In Zambia the poverty rate would be 78 percent.

Figure 6: The level of expenditures at which grade 5 completion is nearly universal is very high...

Figure 6a: ...the $95^{\text {th }}$ percentile in Brazil in 1996...

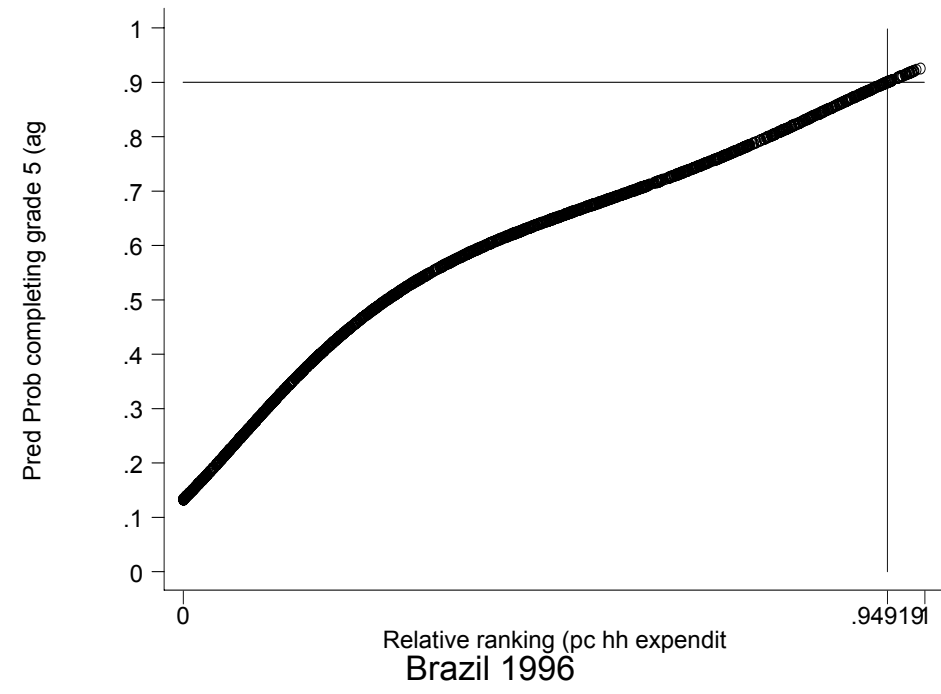

Figure 6b: ... and the $99^{\text {th }}$ percentile in Nepal...

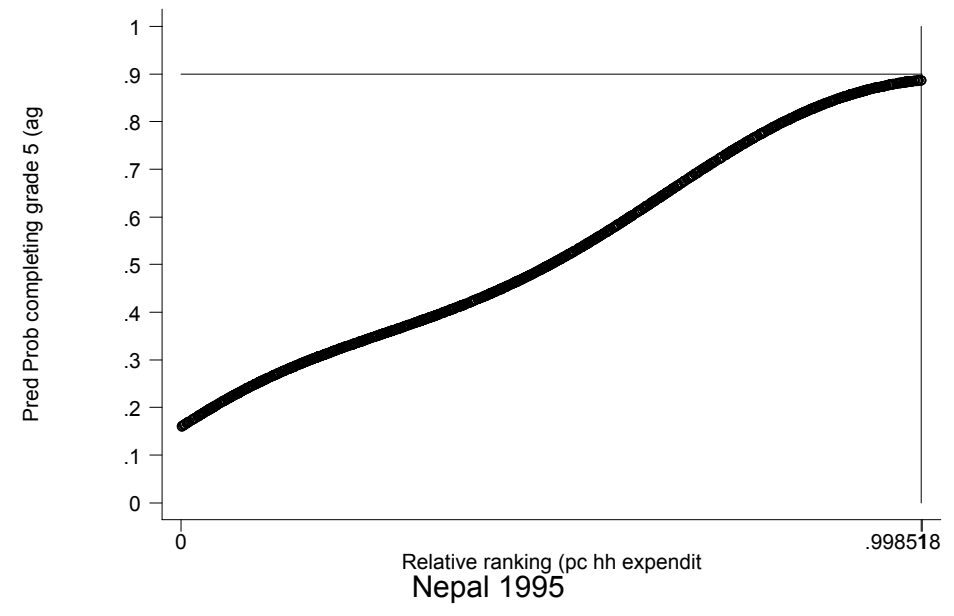


Figure 6c: ... and the $78^{\text {th }}$ percentile in Zambia

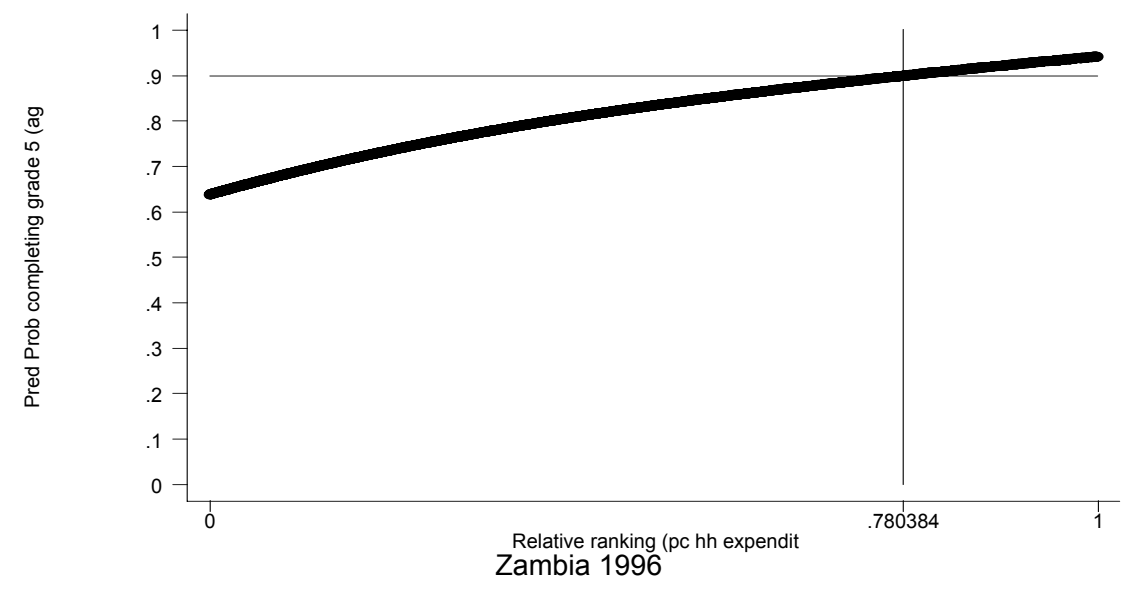

I want to emphasize the physical indicators of well-being not only to defend the reliability of purchasing power adjusted incomes as an indicator of living standards across countries and not only to show that the poor by an international standard of $15 \$$ day do experience deprivation. But I also want to argue for an absolute international standard of poverty ${ }^{20}$. One response is to make "poverty" entirely a relative concept by arguing that an individual's well-being is entirely determined by relative status and that "poverty" is exclusively something like "being able to appear in public without shame" and hence if one lives in a very poor community then even low levels of income make someone "not poor." But I cannot bring myself to argue that everything is relative to one's "community" and that another family losing a child to death from infectious disease does not mean they are "poor" because they live in a community where other people are poor.

Q: Life is about more than money, and certainly the relative importance of money versus other determinants of well being declines as people become wealthier. Does this justify using a low poverty line that discounts increases in income above a certain threshold?

A: While there may be some threshold above which income "no longer matters" either in individuals well-being or a legitimate poverty objective, all the evidence suggests this is at a high, not low, poverty line.

While economists as a group tend to reject paternalism (judging other individuals choices as more or less valid or wise) there is the possibility that what people really care about in other people's welfare is not their overall level of consumption but rather their achievements on certain physical indicators. So perhaps a rationale for a poverty line is that "above a certain level of spending people are just buying TVs and SUVs and air conditioning and they don't really 'need'

\footnotetext{
${ }^{20}$ For instance, Atkinson and Bourguignon (1999) have proposed a different possible reconciliation of the low poverty lines with the relativity of poverty that allows the poverty line to vary across countries. The use of national poverty lines that are based somewhat or entirely on the basis of relative income for national comparisons and policy is perfectly appropriate. However, while I am sympathetic to the notion of relative comparisons, I am nervous about setting a standard as "internationally comparable" that assigns different individuals different levels of real income as "adequate" depending on where they live.
} 
that stuff, in fact, as people get richer they just consume more out of social pressures and are not really any happier, so giving zero weight in the social objective function is a reasonable approximation since it is very low anyway." While I could perhaps be persuaded to buy into that rationale for some line it is impossible to believe that argument for a low poverty line. At the low poverty lines health is improving, nutrition is improving (and marginal propensities to spend on food are "high"), subjective well-being is improving, and it is hard to

Imagine the following: First specify any indicator of well-being that the international community values. Second, establish a threshold for increase in that indicator with respect to income below which further increases in income "don't matter." Then, using the empirical relationship between income and social indicators and a flexible functional form that allows the relationship to vary across levels of income examine the point at which the derivative of the improvement in the valued indicator of well being drops below the threshold. Then we could say "above that line money does not matter."

While not wanting to pre-judge the results, it is difficult to see from eyeballing the data on a variety of social indicators how it could possibly be that the marginal impact of additional income in improving child morality, food consumption, malnutrition, school enrollment is either "near" zero or "rapidly declining" anywhere near a low poverty line.

Child mortality is the physical indicator of well-being that I know the best so I will use that as an illustration. In neither the cross national nor the cross sectional within country data does the data appear to suggest a dramatic fall in the productivity of income in generating mortality decreases, until perhaps very high levels of income. In fact, in the cross national data, it is not clear that the functional form is not about exactly logarithmic - that the proportionate change in child mortality to a proportionate change in average national income is not (roughly) constant over the entire range of observed incomes. Examine figure 7 -it is very hard to say where one would draw a line through that relationship such that income "no longer matters" for reductions in mortality above that line. Certainly not at P\$547 (on the $\mathrm{x}$ axis of the figure, $6.3=\ln (547)$ ), and in proportionate terms not even at the level of the higher poverty line $(8.6=\ln (5475))$. 
Figure 7: Infant mortality falls roughly proportionately with average national income over a very large range of incomes...

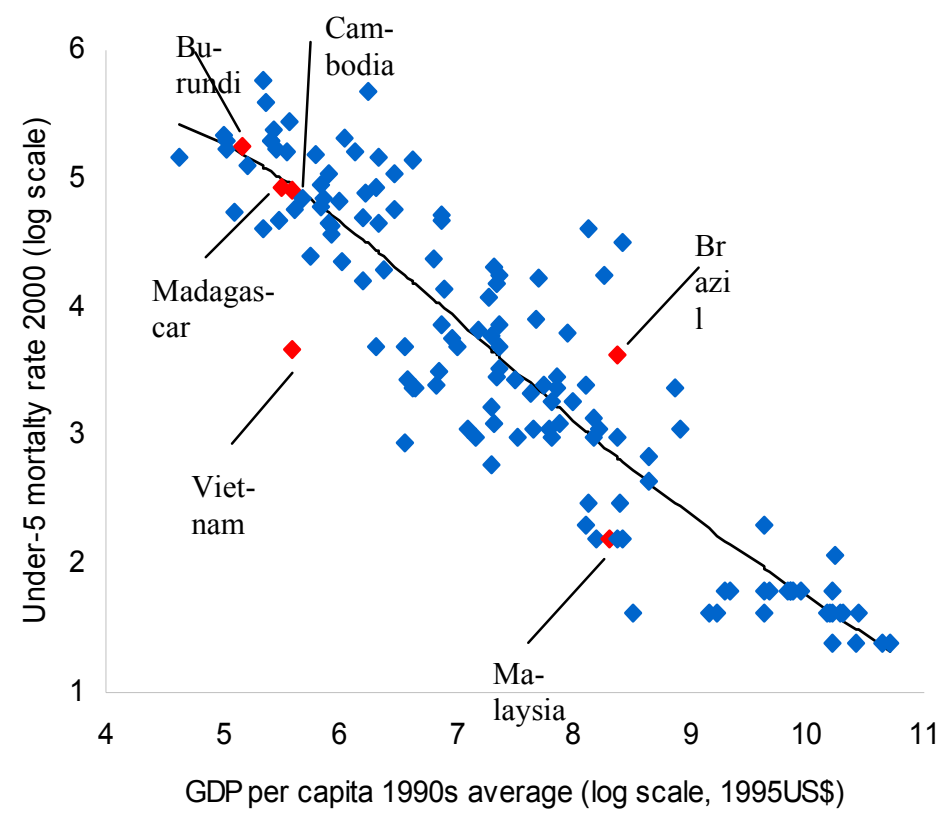

\section{Source: WDR 2004.}

So, suppose one made the argument, "I don't really care about people's total consumption, I only care about improvements in child mortality and therefore I am comfortable with a social objective function that places zero weight on income increases in the range of income in which income stops improving child mortality." This is a not implausible sentiment, but can it justify a low poverty line? No. This could perhaps justify a high poverty line (but even there the evidence is not so clear as, since the impacts are roughly linear in logs, it depends on where one is willing to establish the absolute threshold).

Food consumption. It is well known that the marginal propensity to consume on food declines as income rises. What is the threshold for spending on food at which "we" don't care about gains to the income because they don't spend "enough" on the increment food? Whatever the level, "we" can then use regression to identify that threshold. But given the very high food shares and reasonably high food income elasticities these will not be very low at the low poverty lines.

Subjective well-being. Finally, there is a growing sense, especially in rich countries, that economic growth as a goal has been overstated and that increases in income really do not lead to increases in well-being. One could easily see how this increasingly popular sentiment among the well-off could turn into support for a low poverty line since "life is about more than income anyway." Fortunately, Inglehart (1997) based on the household surveys in many countries has established that there is in fact declining marginal utility to income and that the relationship between reported well-being country average income does in fact "flatten out." There is a set of coherent values that he calls "post-materialist" that do focus more on subjective well-being from 
"lifestyle" versus "income" gains.

But does this happen at $\mathrm{P} \$ 547$ ? P\$1094? No. In fact, all countries (but two) with GDP per person above P1990\$15,000 have higher average subjective well being than any country with income below this level. This is consistent with the subjective poverty lines. As the subjective poverty lines do increase, both with the income of the respondent and hence the reported amounts also tend to increase with the average income of the country and do not stagnate at very low levels ${ }^{21}$.

As Inglehart argues, for rich citizens to project values based on their own ability to take basic survival for granted due to their own affluence onto the objectives of people with different material circumstances or onto a poverty focused international organization would the worst sort of confusion about the relationship between values and material circumstances.

Figure 8: Average subject well-being increases with average national income up to very high levels-perhaps tapering off above P\$20,000 (in 1990 terms)

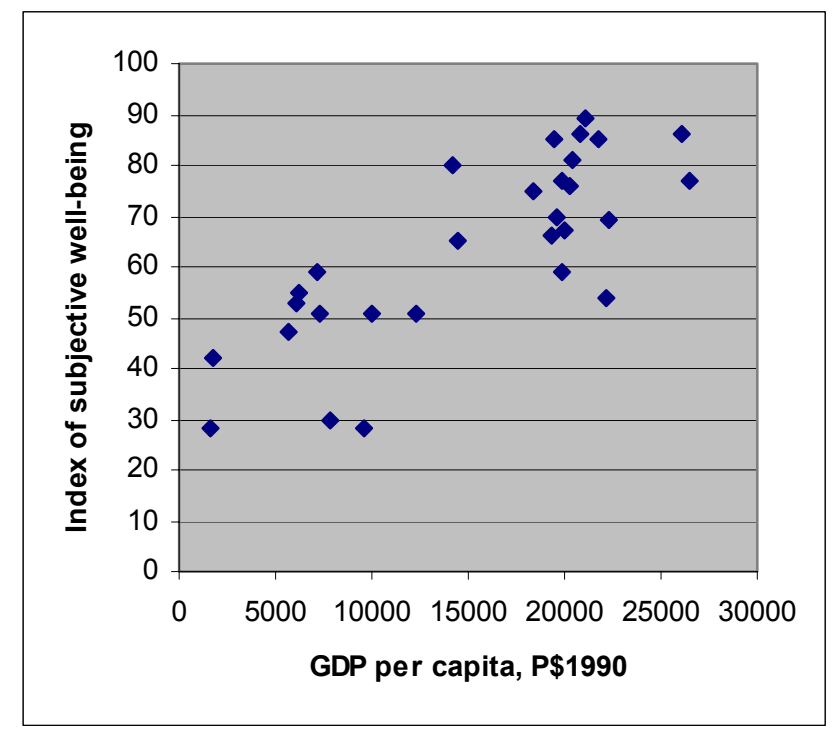

Source: Inglehart (1997) and Penn World Tables data.

\section{Implications of a higher poverty line for the World Bank}

Using a low poverty line has the twin and related dangers of not providing a solid foundation for the range of initiatives that are in fact important for development and setting the organization up for failure. In contrast, a high poverty line for global income poverty used with poverty measures that measure the intensity of poverty (and combined with other indicators and vulnerability) avoids these dangers.

\section{II.A) A low poverty line is a needlessly narrow foundation for development}

\footnotetext{
${ }^{21}$ Again, this does raise the question of whether the subjective poverty lines are driven by "relative" concerns (that is, whether people are concerned about inequality per se) or whether the higher reported poverty lines with higher income is because there is a different absolute threshold of what is "inadequate" or "unacceptable" or "too little."
} 
There are three problems with taking PRO-LPL(Poverty Reduction as the Objective-Low Poverty Line) seriously compared to PRO-HPLIW (Poverty Reduction as the Objective, High Poverty Line, Intensity Weights) ${ }^{22}$. This makes it clear that I am not comparing poverty reduction as an objective to not having poverty reduction as an objective but that I am comparing poverty reduction as an objective with alternative definitions of the appropriate social convention for the international community to adopt in defining an income poverty line.

First, PRO-LPL cannot support the range of new areas that nearly all development practitioners are convinced are important parts of the development agenda while PRO-HPLIW can. Take corruption. Most people are convinced that attacking corruption is an important part of the development agenda. But if PRO-LPL is taken seriously then only the benefits from reducing corruption to the destitute count as a "gain" to reducing corruption from a poverty reduction agenda. In places like Indonesia where low poverty lines imply only about one in ten are poor this would mean that if a reduction in corruption saved every person in the economy a dollar, only one in ten of those are "poverty reduction." Even if the anti-corruption effort were "poverty focused" and saved each poor person twice as much as every non-poor person it is still the case that the vast majority of the benefits go to the non-poor.

So it is more or less impossible to rigorously justify a wide range of new initiatives that development practitioners think are important and which, almost of necessity, have widely distributed benefits: reducing corruption, protecting the environment, improving public services (e.g. increasing the quality of education) under PRO-LPL because all gains to the non-poor do not count to a poverty reduction objective and with low poverty lines even in very poor countries like Bolivia only 11 percent are poor, in Cote d'Iviore only 12.3 percent are poor, in Indonesia only 15.2 percent are poor,

Second, with strict PRO-LPL it is impossible for the World Bank to work in a wide range of countries. If, by its own measures, 94 percent of Sri Lankans are not poor then can the World Bank justify working in Sri Lanka? Even with actions that were very sharply targeted most of the benefits will go to the "non-poor." Now, since the national poverty line (quite reasonably) says that a much higher fraction of Sri Lankans are poor, why start with a global line and move up? Why not start from PRO-HPLIW and then, if countries choose to have even more aggressive definitions for their current national circumstances move down. The range of countries with less than ten percent poverty at a low poverty line is long: Morocco, Thailand, Romania, Russia, (and nearly all the former USSR), Brazil, Dominican Republic, Egypt, Sri Lanka, Yemen. Does the World Bank really think that these countries have essentially no income poverty at a reasonable standard and hence the World Bank should not be engaged in these counties on broad development issues? ? $^{23}$

\footnotetext{
${ }^{22}$ For the "low" poverty line I use the $1 \$$ /day because it is the most widely cited and the only one with any even putative "foundation" as once we admit that it is possible, just to get more plausible results, double the poverty line then we are off to the races - if double why not triple, why not quadruple, why not, as a propose is reasonable tenfold to a level that is as equally grounded as the $\$ 1 /$ day standard.

${ }^{23}$ This is not an idle argument. One of the lines of attack of the Meltzer Commission was, crudely summarized, exactly this- "if poverty is your objective get out of most countries." A reasonable definition of global income poverty dissipates the force of this argument immediately. This does not mean the World Bank should change its objective from poverty reduction to promote its relevance - the World Bank should stick to its original objective of
} 
Third, broad based (e.g. distributionally neutral) economic growth is hard to support as a key in most countries with PRO-LPL. That is, since with a low poverty line "the poor" get a very small share of output then it is also the case that very little of a distributionally neutral increase in income goes to the poor. Take Cote d'Ivoire where only 12.3 percent are poor and, according to the distributional information the bottom ten percent get only 3.1 percent of the income. Now, suppose that, by adopting some sensible policy reforms, output per person could be 10 percent higher in Cote d'Ivoire leaving the distribution the same. With a high poverty line this is unambiguously a huge success.

But if PRO-LPL is taken seriously the response to this could be "the economic reforms have had very little impact--only 3 of every 100 dollars of gains have reached the poor!" This statement is perfectly correct and unreasonable only if one rejects the notion that 88 percent of people in Cote d'Ivoire are "not poor." Given that average infant mortality was almost 100 and stunting affects a quarter of all children and only finish sixth grade, I think it is pretty convincing that any poverty line that says 88 percent of Ivoirians are "not poor" for the purpose of assessing the impact of economic growth is not an appropriate standard for the international community to adopt.

One view is that "income redistribution is hard to do so poverty reduction must be based on broad based growth." But I argue that poverty reduction with a high poverty line recognizes that the income gains to those households that are global poor by a high poverty line are important in their own right. An exclusive focus on a low poverty line implies that "pro-poor" growth is limited to "pro-destitution" growth.

Fourth, PRO-LPL is inconsistent with the spirit, if not the letter, of Millennium Development Goals (MDGs) while PRO-HPLIW is not. Given the attention the MDGs have received and the priority they are for the international community it is a bit surprising this point has been missed. This is an obvious implications of the facts above about the relationship between physical indicators of well-being and the low poverty lines. Suppose that, somehow, we could meet the MDG for reduction of "extreme poverty" but not raise the incomes of the non-poor (which is the case for a "perfectly targeted" transfer). If the poverty objective were met would the target for "hunger" (if measured as actual malnutrition) be met? No, malnutrition is high among the non-poor by a low poverty line. Would the MDG target for infant mortality be met? No, infant mortality is high among the "LPL non-poor." Would the MDG target for universal primary completion be met? No, failure to complete primary is high among the "LPL non-poor."

Reaching the MDGs will require broad based increases in incomes because increasing the incomes of the non-poor by low poverty line standards will be hugely important to reaching the MDGs ${ }^{24}$. This is exactly what a high poverty line approach to poverty reduction would sup-

broadly defined poverty reduction because it was good for promoting human well-being.

${ }^{24}$ This raises another debate, which is whether somehow improved public action without increases in income could be sufficient to reach the MDGs without increases in income. One can, with sufficient dint of effort in ignoring the real world and the evidence, imagine a combination of highly targeted poverty transfers and improvements in public action aimed specifically at the MDGs that could achieve the MDGs without substantial, broad based gains in incomes. The cases of the world's few outliers in having good indicators with low levels of income-e.g. Kerala, Cuba - are cited over and over again while the fact that, for every major indicator of physical well being the over- 
port and which PRO-LPL does not.

The danger of rhetoric is that someone might actually take the rhetoric seriously. The World Bank is constantly saying things like "poverty reduction is our primary objective" and "everything we do should be judged in terms of poverty reduction." At the same time, the World Bank consistently reports income poverty measures using exclusively low poverty lines (1\$/day, $2 \$$ /day, nutritionally based national lines). This could lead reasonable people to believe that everything the Bank does should be judged by its impact on people with less than these amounts. But this is setting the Bank up for failure because there is no way that actions that are sufficiently broad to meet development objectives can be a "success" in most countries on these narrow grounds. Suppose the World Bank launched a project to improve educational quality in basic schooling Indonesia or Brazil or Turkey that for a cost of $\$ 100$ million dollars created a $\$ 100$ million per year worth of benefits for 20 years and suppose that these benefits were distributed evenly across all students. By any reasonable standard this project should be judged a huge success. But, under PRO-LPL this project is a huge failure because "most" of the benefits went to the "non-poor."

I want the World Bank to take poverty reduction as its primary objective seriously and literally--but to do so requires a much higher line for income poverty. While the explicit emphasis on poverty reduction as its objective is an important advance for the World Bank combining a poverty reduction objective with a needlessly narrow and crimped definition of income poverty risks changing the World Bank from what the world needs and wants - a development institution focused on broad increases in living standards and well-being in the developing world into something else - more like a relief or charity institution. The organizational objectives of the World Bank are perfectly consistent with poverty reduction as the key objective only if a high poverty line is used. Poverty reduction with a low poverty line simply cannot support the broad range of interests that the organization should pursue in the interests of correctly interpreted poverty reduction - in governance and reduction of corruption, in infrastructure, in broad based economic growth and the investment climate, in the more effective provision of services, in social protection and is inconsistent with reaching the Millenium Development Goals.

\section{II.B) Are low poverty lines defensible in an international organizations?}

It is hard to see on what grounds the Bank shareholders would, or could, oppose this method of defining poverty. No one expects countries to devote the same level of resources to poverty in other countries as in their own and nothing about sharing a poverty line implies this. But how can one country say to another country in an international forum "We adopt one standard of living as poverty for our own citizens but for your citizens we think a much lower level of well-being is sufficient."

So, while any country can define poverty however they see fit and which is most useful for their own policy and political purposes, suppose any country, in their PRSP decides to take the position they define their poverty line as that of the USA or Denmark or Germany and for poverty intensity use a reasonable poverty aversion parameter. What argument that could made

whelmingly most important determinant across countries is the level of income, usually followed by maternal education. So, obviously some combination of improved public action and broad based growth is the right strategy. 
against this by the World Bank? I can picture a government taking the stance in an international forum that:

Poverty reduction is our objective, but we are not going to be talked by an international organization into narrowing our national objective so that we aspire to less for our citizens than the governments of other shareholder countries do for their own citizens. Our position is that the citizens of our country have exactly the same rights and aspirations in the international system as do those of any other country and that would should be able to expect international assistance to support us in reaching that goal.

Particularly with the developing countries playing a larger and more aggressive role in the international system, international equity would suggest the use of a set of common global standards.

\section{III.C) Is a low poverty line really good for the poor?}

One fundamental defense of a low poverty line is the, usually implicit, claim that a "low" poverty line will be good for the poor. That is not at all obvious, and certainly there is no empirical evidence to substantiate that claim. Since a poverty line is a social convention intended to generate "pro-poor" policies it is an open question whether adopting low or high definition of a poverty line will be more instrumentally beneficial.

First, it is not obvious that PRO-LPL is a politically viable stance domestically for a democratic government. At a recent conference on poverty a high level policy maker from the most recent Congress government in India expressed his irritation with the narrow poverty agenda saying something like ${ }^{25}$ — "The World Bank guys were making themselves irrelevant by saying 'poverty, poverty, poverty.' Didn't they realize that we had to be the government of all Indians? We couldn't go into an election having ignored the desires of most of the electorate simply because we want to benefit 'the poor' exclusively." Similarly, one of the first directions President Lula of Brazil sent was that he was the president of all Brazilians. A poverty agenda that specifically identifies a small(ish) minority of citizens based on an arbitrary threshold and privileges their claims to attention is not obviously a winner and there is no evidence to suggest that low poverty lines (at the national or international level) are more favorable to creating a domestic political environment to improve human welfare.

Politics or any positive model of policy is not formalized into poverty analysis. This means that while PRO-LPL might be a nice analytical device or rhetorical stance, in the real world policy advice might be completely, wrong. In a simple voting political economy model it can be shown that a policy maker who insists on treating poverty reduction as the sole objective and ignores the responsiveness of the budget constraint to targeting can actually lead to the worst possible outcome for the poor and the best for the rich ${ }^{26}$. That is, the strongly pro-poor but po-

\footnotetext{
${ }^{25}$ This was during the "discussant" section so there is no written text. I am paraphrasing.

${ }^{26}$ Again, in simple political economy models with three groups the rich most prefer a strong "poverty reduction" objective as they prefer a "rich-poor" coalition with low taxes to fund highly targeted transfers to higher tax rates and higher social transfers - and higher social welfare by any standard metric. So "narrow pro-poor" rhetoric is, in these models, a tool of the rich.
} 
litically naïve policymaker by insisting on high targeting undermines support for the taxes to finance redistribution. There is sometimes a tendency to assume the PRO-LPL crowd is on the side of angels while a a high poverty line implies les concern for the poor but the opposite might well be the case as in voting models the PRO-LPL is the close political companion of fiscal conservatives with no concern at all for the poor. While I am not suggesting this model is the last word or is more than an illustrative example, it is not the case that one can devise "optimal" policies in an office on $\mathrm{H}$ street and then simply assume that this optimal advice applies in a real world, which is a political world and the only issue for politics is getting the "optimal" policy adopted.

While PRO-LPL and "targeting" are not synonymous a low poverty line (and hence few poor) makes redistribution seem a more feasible and attractive way of attacking poverty. However, it is not obvious that targeting is "pro-poor" either empirically or theoretically. There was a proposal in the United States Congress to place an income cap on benefits from the retirement system for the aged so that people with earnings more than $\$ 200,000$ (almost seven times median $\mathrm{HH}$ income) had their benefits capped. Newt Gingrinch the Republican leader favored capping benefits for the rich. Charles Rangel, the African American congressman representing Harlem strongly opposed capping the benefits of the rich. It should at least give pause in taking the view that the "low poverty line" by focusing on the "poorest of the poor" is the "progressive" view that many of the examples of successful targeted programs are from Pinochet's Chile.

Second, there is just no empirical evidence that having or not having a low poverty line is good or bad for poverty reduction (however measured). Moreover, it is hard to say exactly how one would prove this. The United States has an explicit poverty line and most European countries do not. Yet I have never heard anyone argue that the USA has done a better job of attacking poverty than European countries - and many people do argue the opposite, with substantial evidence $^{27}$. Now, of course, perhaps given its history and circumstances the USA did better at poverty reduction with a poverty line that it would have otherwise - but again, I have never heard anyone defend this claim. Many would argue a large part of reduction in poverty in the USA has been the result of non poverty oriented programs (such as Social Security) and not the targeted programs.

Third, the low poverty line approach tends to focus on "the poor" as a group. It is not clear this has any empirical content - see appendix 3. Moreover, for pragmatic purposes this can be dangerous as talk about "the poor" can easily slip into a mode which treats "the poor" as distinct, or alien, a group who is different from the rest of us. Again, while I am sure none of the PRO-LPL advocates mean this to happen talk of the sort: "'the poor' live here" and "'the poor' do this" can easily slip into what Latin Americans label "asistencialist" the attitude that "we" are here to "save" the poor. While the empowerment agenda is fighting against this the defining of an exclusive low poverty line works against it. On the other hand, with a high poverty line in most poorer countries it is clear "the poor" is the body politic and "them is us" and poverty reduction is a shared national project.

Fourth, a narrow vision of poverty reduces the ability to take a broad strategic vision to

\footnotetext{
${ }^{27}$ A recent book using panel data comparing the USA and two European countries showed that the European countries essentially eliminated chronic poverty and the USA had not.
} 
social policy. People confronting the problems in Latin America, such as Nancy Birdsall, are pushing the view that a broader, more strategic and inclusive view to social policy is a better approach for the poor than pushing a narrow poverty definition.

\section{II.D) Does it matter at all?}

Finally, defenders of the use of low poverty lines would argue that even though the Bank uses these poverty lines in "sound bites" this does not create any harm because the "real" poverty analysis is much more sophisticated and does not take the single poverty lines as seriously as it might appear. I would argue against this view that a certain amount of organizational saying one thing and doing another is acceptable on three grounds. First, while the approach of some analysts of poverty is in fact very much more sophisticated and subtle that taking a single low poverty too seriously, that is just not true across the board and the low poverty lines often put analysts in a straight jacket.

Lastly, it is not clear it is a long-run good idea to not mean what one says in a pretty literal way ${ }^{28}$. While everything the World Bank does (when it does things well) can be justified by income poverty with a high poverty line and intensity weights, PRO-LPL taken literally cannot be the basis for most of what the World Bank currently does. This is not an idle argument as it is put forward, often. It would be easy to argue against many of the recent initiatives of the World Bank - in the environment, on corruption, on social capital--on the grounds that they are not especially focused on the poorest of the poor as defined by the low poverty lines. A reasonable definition of global income poverty dissipates the force of this argument immediately.

\section{Conclusion: I come not to bury poverty reduction but to raise it.}

Nothing is lost and much would be gained by moving on from the first generation of low income poverty lines and adding a new definition for a poverty line for "global income poverty" that is (roughly) 10 times higher than the present standard. This higher level is internationally fair, realistic for policy, a solid organizational foundation for assistance agencies (including the World Bank), and, incidentally and perhaps least importantly, more consistent with existing economics. This change in income poverty line standard should be, of course, accompanied by the ongoing incorporation of other measures of deprivation and vulnerability into poverty reduction $^{29}$.

An income poverty line used to define the "poverty" in a poverty reduction objective should be able to meet two criteria. The exclusive use low poverty lines (\$1-2 \$/day) as the international standard for poverty at the World Bank fails both of these criteria.

\footnotetext{
${ }^{28}$ I may be old fashioned, but I was very influenced by Horton the Elephant from Dr. Seuss. After being subject to ridicule and abuse for sitting on an egg after promising someone he would do so, his response was: "I said what I meant and I meant what I said and an elephant is faithful one hundred percent."

${ }^{29}$ That is, nothing about my argument should be taken as asserting the importance of "income poverty" versus other components of the complex, mutli-dimensional social reality of the phenomena of poverty. Nor does anything in my argument suggest any internationally comparable line should have weight in national discussions to set relevant national income lines. But if we are to measure and widely report income poverty at a common international standard then let us have the conversation about what standard the international community wishes to adopt.
} 
First, since income poverty is intended to measure "unacceptable deprivation in human well-being" or "inadequate income" (or any similar definition that establishes a threshold) this implies that the suffering of those above the poverty line, while regrettable, is acceptable or is adequate. If the poverty line is set very low then we are sure that people below that line are truly poor-but is the poverty line set so that the deprivation of the "non-poor" is "acceptable"?

The reasonable and fair definition of a poverty line to be used in the World Bank's poverty reduction objective is that the level of human deprivation that is unacceptable for the citizens of industrialized countries should also be unacceptable for all other countries of the world. If the United States feels that a US citizen is poor if they have less than $15 \$$ /day dollars a day then why should less than a tenth of that amount be "acceptable" for an Zambian? Or an Indian? Or a Bolivian?

Infant mortality of those who are not poor by the $2 \$$ day standard is often well above 50 - more than five times the level of the poor in industrialized countries - is that "acceptable" deprivation? Malnutrition of those not poor by that standard is as high as $1 / 3$ of children-is that "acceptable" deprivation? As many as one-half of children who are not poor by that standard are not completing basic education (9 years) - is that deprivation "acceptable"?

Second, if "poverty reduction is the objective" then additional income above the poverty line counts for nothing with respect to that objective. At the poverty line it should be reasonable that further increases in income are not an important social objective.

There may be some individuals whose concern for others ceases after their income exceeds P\$1090 per year, but I am not one of them, and do not think the World Bank should adopt that standard for its primary poverty reduction objective.

There is nothing about the way people behave to suggest that they are not concerned with improving their own well being. People at the levels of income that the World Bank says are "non-poor" make tremendous sacrifices — work long hours, migrate long distances, take on dangerous and unpleasant work--to increase their income and provide a better future for their children. Treating these efforts as worth zero in the Bank's poverty reduction objective dismisses these sacrifices as unimportant. In essence by adopting the low standards the World Bank is telling half the world's population (the difference between the roughly 20 percent $2 \$$ /day poor and 70 percent $\$ 15 /$ day poor) that they don't matter to the organization.

The increments to income at this level are used to buy more food, to increase children's schooling, to improve their and the children's health. Why does this count for nothing? There is absolutely no compelling argument from economics, from ethics, from policy, or from politics for the position that all income gains above a low threshold count for nothing.

The problems created by the combination of poverty reduction as an objective and low poverty lines can be solved very simply: $1 \$$ /day (adjusted for inflation) defines "destitution", 2\$/day (adjusted for inflation) defines "extreme poverty" and "global income poverty" is defined by $15 \$$ day (or some similarly high line grounded in the poverty standards of World Bank shareholder countries). Poverty measures using these poverty lines are computed and reported using 
with intensity weights.

This simple shift in definitions allows continuity and comparability with previous measures of poverty while embracing a new bold vision of what the dream of a world free of poverty really means. 


\section{Appendix 1: Poverty lines are not determined by "scientific" nutritional needs}

A second key myth is that the poverty lines are not an arbitrary social convention about which there can be non-technical arguments, but rather are solidly based on scientifically determined nutritional requirements. Many people think that the low poverty lines are based on what it "costs" to reach a nutritionally adequate diet and that determines the poverty line. But people who actually work with poverty lines know better-while low poverty lines are related to nutritional requirements these do not determine the poverty line. In any given country exactly the same nutritional requirements could imply 5 or 50 percent of the population are poor.

A common procedure for setting a poverty line is to start from a Food Poverty Line that is the "cost of achieving intake of $\mathrm{N}$ calories at a given basket." While this might make it seem as if the nutritional standard of $\mathrm{N}$ calories fixes the poverty line- this is not so. What determines the food poverty line (and causes huge variation) is the basket of food to attain the calories. The basket of foods consumed determines the cost per calorie of the food consumed and the food poverty line is the number of calories (which varies very little) times the assumed cost per calorie which varies enormously.

If one chooses a basket that reaches $\mathrm{N}$ calories at minimal expense then this would provide a "technical" means of determining a food poverty line ${ }^{30}$. But the resulting poverty line would be so low that almost no one is poor - even in very poor countries. A recent paper estimated that an Indian unskilled workers salary if it was devoted to purchasing rice was sufficient to purchase about 10,000 calories a day in the 1700s!

But people, even very poor people, do not in fact eat food strictly to achieve calories. People care about variety and flavor and taste. Therefore, one reasonable approach is to say "the food poverty line is the cost of $\mathrm{N}$ calories with the mix of foods actually consumed by a "reference group." While this is a perfectly reasonable approach it should be acknowledged that this changes for food poverty line from being "nutritionally" determined to determined by a social convention. The key question is who is the reference group? While there are a variety of plausible ways to answer this question, none of them are more or less "scientific" than any other and the answers make a huge difference.

For instance, if in El Salvador if the rural poverty is measured using the average consumption basket of rural households then 29 percent of the rural population are below the food poverty line. However, if rural poverty is calculated using the cost in rural areas of the average urban consumption basket then 48 percent of the population is below the food poverty line. Just by changing the definition of which group - average rural or average urban consumers - was the "reference" group whose consumption basket would define the poverty line one can change the poverty headcount by 20 percentage points. The reason is easy to see- the urban basket includes consuming more fruits, more vegetables, more meat, more white bread—in all, a much more pleasing diet.

The caloric intake based poverty lines are not nutritionally determined but are determined

\footnotetext{
${ }^{30}$ This could also be extended to a more complex linear programming problem of achieving nutritional adequacy for a number of requirements besides calories (e.g. vitamins, proteins) at minimal cost, with roughly the same result.
} 
by a social convention about the food basket. There are two points. First, the choice of basket is entirely circular and entirely an arbitrary social convention there is not technical or economic theory based reason why the food poverty line should be based on a food basket that is caloric intake cost minimizing or the basket of the household with median income or the basket of the household with average income or the basket of the household in the bottom 10 percent or whatever $^{31}$. The food basket to define poverty is chosen by a "conversation" about the level of well being that people should have when they are defined to be poor.

Second, once it is emphasized that the food poverty line is determined by the choice of the quality of foods in the basket and that is a social convention about the level of well being that defines poverty--then it is no longer clear why food has pride of place or is prioritized. That is, if the quality of food in the food basket is determined by a "conversation" about the appropriate level of well-being at which it is appropriate to say people are "poor" in a given social situation then why not housing? clothing? transport? costs for health care? In fact, a "subjective" approach to setting poverty lines - simply asking people what they think a poverty line should be-is a common approach and has equal "scientific" legitimacy as the nutritionally based approaches as both are equally determined by social convention ${ }^{32}$.

It is important to explode the myth that the poverty line is "nutritionally determined" in order to emphasize that ultimately as a social construct poverty is a convention. Each society has to come to its own definition and there are no technical grounds for saying this is a "good" poverty line or a "bad" poverty line ${ }^{33}$. Which leads us back to the question - what is the standard the international community wants to adopt as the global "social convention" for poverty?

\footnotetext{
${ }^{31} \mathrm{I}$ have proposed in a paper elsewhere (with co-authors) that just to have a complete and consistent method for defining a poverty line one should iterate to convergence so that the "reference" group are people at the poverty line. This is a useful and workable convention and would avoid the problem of different poverty lines just from confusion about the reference group — but as a convention for poverty line definition it is just as arbitrary.

32 There is a body of survey research on subjective poverty lines. My limited reading of this evidence is three-fold: a) on average subjective poverty lines do not produce poverty lines wildly inconsistent with other methods, b) people's perceptions of poverty lines are widely dispersed, strongly dependent on their own income, and do not strongly cluster around any given poverty line which belies the notion that there is some deep consensus notion of a poverty "threshold", c) at least some of the findings from subjective poverty lines are not consistent with existing treatment of household economies of scale in the World Bank. Some research in the United States suggests subjective poverty lines are substantially higher than the current US poverty (not surprisingly as the US poverty line has been held constant) which makes the above points about adopting OECD poverty lines even stronger.

${ }^{33}$ Within an overall poverty line there are desirable criteria for how it varies across households, regions, time, etc.
} 


\section{Appendix 2: "Poverty" analysis is not grounded in economics}

Even though it has been mostly economists who have promoted it poverty lines, and in particular low poverty lines, poverty lines have no widely accepted grounding in standard economics or wide acceptance by economists ${ }^{34}$. In conversations one of the principal users and defenders of low poverty lines within the World Bank agrees fully that poverty lines are inconsis-

tent with standard welfare economics — but argues that it is economics that should be changed ${ }^{35}$. On one level I am pleased that we agree on that key point: that "poverty" analysis is not grounded in standard welfare economics. We do however disagree as I think the economic approach to normative judgments about social objectives at much more defensible and wellgrounded than the use of low poverty lines while using poverty analysis with high poverty lines is plausible.

The key difference between standard social welfare economics and poverty analysis is that standard welfare economics takes the approach that if a person in a society considers $\mathrm{him} /$ herself better off then society is better off ${ }^{36}$. The most widespread approach to poverty analysis says that above some threshold increases in the well-being of individuals counts for zero. While there is nothing technically "wrong" with such an objective function, and, I could even be persuaded that, in principle, there is some threshold above which income gains should not count in social objectives so that a "poverty reduction as objective" is a useful approximation.

\footnotetext{
${ }^{34}$ This is putting it mildly. I have never met a single economist who honestly believed that "reduction of income poverty with a low poverty line" was sound as a sole (or even primary) objective of policy making (except in perhaps very very poor countries where a low poverty line still incorporates most of the population) while many do believe that something like an inequality averse social welfare function is a (reasonably) sound foundation for normative discussions of policy.

${ }^{35}$ Email communication with the author.

${ }^{36}$ A perfectly reasonable criteria for an adequate social welfare function is that in comparing situation A to situation $\mathrm{B}$ if (at least) one household is better off and no other household is worse off then the social welfare function should judge situation better in A than in B. Of course, even in a social welfare function one could make this weaker and not "count" welfare gains above a threshold and still satisfy a weaker axiom for a social welfare function.
} 


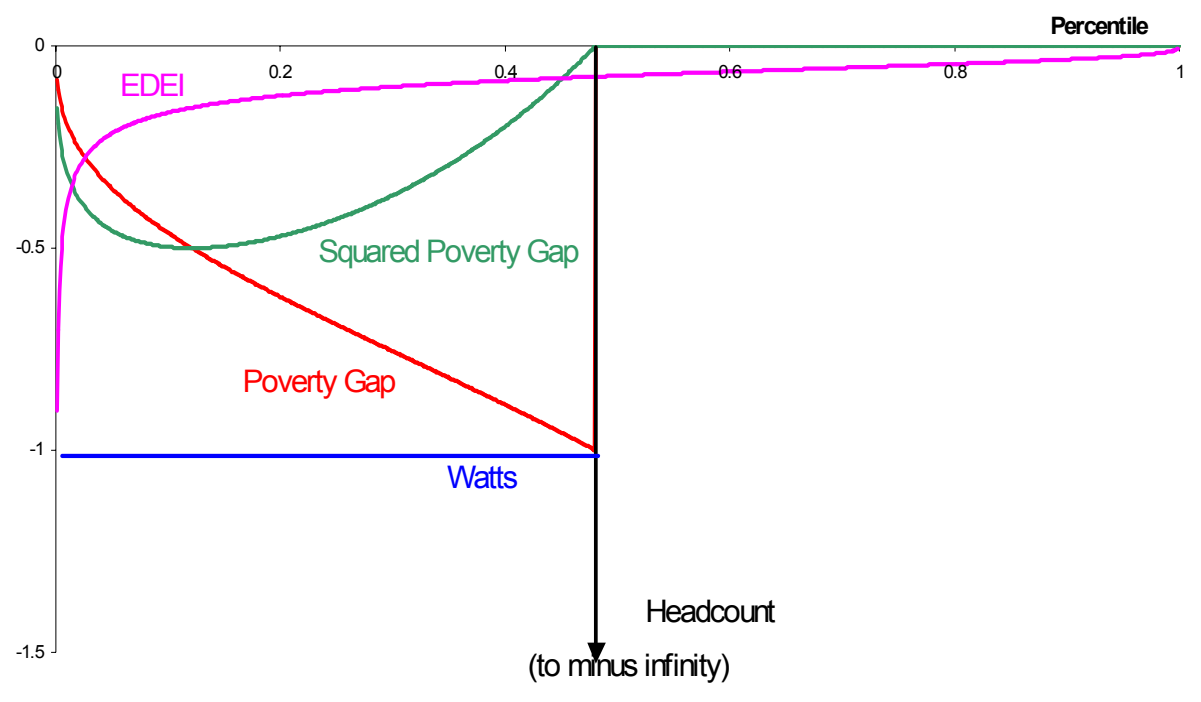

But I would argue the combination of "poverty reduction" as the social objective and a low poverty line (PRO-LPL) cannot be defended on any grounds. A low poverty line draws an arbitrary line through the distribution of incomes and says "gains to people below this line do count and gains to people above this line count for zero even though they are only infinitesimally above the poverty line and even though their standard of living is absolutely very low. With PRO-LPL the ratio of the gain in objectives from an increase in income of someone below the line to someone just above the line is infinite (since one is dividing by zero). In contrast, most people would think, as would any social welfare function, that the gains to the poor person are more important but not infinitely more important. Let's suppose we were very inequality averse and wanted an equivalent gain to the poor person to be 10 times as high as the non-poor person. How bad an approximation for 10 is infinity? Well, on some level, infinitely bad. While this same theoretical problem exists with a high poverty line, the problem is, in a practical sense, much smaller because at the margin the gains from additional are still large at low poverty lines.

There are three ways between standard welfare economics and poverty analysis matters and to which I think standard welfare analysis gives a more reasonable answer.

First, suppose I take poverty reduction as my only objective and adopt a low poverty line. Then the incomes of people marginally above the poverty line count for zero so that a policy of a hugely regressive tax born by the less well-off (but not poor) with the revenues transferred to the poor in some very inefficient way (say only $1 \$$ of every $10 \$$ of taxes actually reached the poor and the rest was spent in administration) is a poverty reducing by social welfare worsening policy. Which mode of analysis is more plausible?

Second, suppose a low poverty line shows that $15 \%$ of the population is poor and suppose there is an investment of $\$ 1$ that would that would raise everyone's incomes by the same equal, quite large, amount. Unless the amount going to the poor exceeds the cost of the investment then from a PRO-LPL perspective this is a bad investment while from a social welfare point of view this is a good investment if the inequality weighted income increases by more than the inequality weighted costs. 
Third, suppose one has a transfer program to the relatively poor that reaches half of the poor and half of the group just above the poverty line but well below median income. By PROLPL standards that money is "mis-targeted" and the amounts to the near, but not poor, are "leakage." By standard welfare analysis the degree and cost of mis-targeting is weighted by the income of the person receiving the transfer so the welfare cost of the "mis-targeting" could well be very small ${ }^{37}$ as opposed to the PRO-LPL view that half of the money transferred had no value.

The response by PRO-LPL advocates could be two-fold. One response is that these are contrived examples and that PRO-LPL "mostly" agrees with welfare economics over the relevant range of policy proposals but this is not a strong defense $\mathrm{s}^{38}$.

More tellingly, PRO-LPL "well, that is literally true, but we are not so unreasonable as to actually mean what we say. You don't actually believe those 'sound bites' about the number of poor and poverty as the objective, do you? Of course in considering any policy can always do a robustness check by examining how robust policy conclusions by doing the poverty analysis at various poverty lines."

But there are three counter-responses. First, this robustness across a wide range of poverty lines isn't in fact done-except for the fact that analysis often uses two poverty lines (one "extreme" and another "less extreme" or "the poor" and "the near poor"). While there is some very sophisticated and subtle poverty analysis there is also a fair bit that does take PRO-LPL pretty literally. Second, even if one does a robustness check wherever you do stop you still have the same problem - people above the line do not count at all. Why not go all the way to $\$ 15 /$ day to do a "robustness" check? I will argue below that, especially for the World Bank a number like $\$ 15 /$ day has much more rationale than a penurious line like \$1/day.

This does raise the question, if poverty lines and in particular a low poverty line is not grounded in economics why did it originate (among economists) and why has it persisted?" My reading is that there are two reasons.

First, at a certain point in time low poverty lines made for good public relations and economists were willing to provide the "sound bites" (e.g. "there are X billion poor in the world") necessary for such PR. In fact, in earlier conversations with users and producers of poverty numbers using low poverty line one of the principal defenses of low poverty lines is that they were harmless because there were just sound bites and no one really took them seriously ${ }^{39}$. I agree that no one should take low poverty lines seriously, but disagree that (a) one should persist in promoting numbers that are just sound bites and (b) I worry that low poverty are being taken more literally and more seriously than their originators ever intended - with negative consequences.

\footnotetext{
${ }^{37}$ Emmanuel Skoufias has an analysis which suggests this is true.

${ }^{38}$ It is not clear how one would empirical is, if people don't make proposals such as the above because they do not in fact believe in PRO-LPL so PRO-LPL is roughly right over the range of relevant proposals precisely because PRO-LPL is not a relevant generator of policy recommendations whereas if people were to take PRO-LPL seriously they would have conflicts with standard welfare analysis.

${ }^{39}$ Email communication with the author.
} 
Second, many economists who use PRO-LPL argue that, even though they know it cannot be rigorously defended as sound economics will say that it is "simpler" to present to policy makers. Perhaps that is right, but then the real issue is not between a low poverty line and a high poverty line but between using a headcount index and an intensity weighted measure of poverty. But even the staunchest defenders of low poverty lines know that headcount poverty rates cannot be taken seriously as an objective. So anything that can be said about the "simplicity" of poverty analysis over social welfare function analysis can also be said for high poverty lines.

"Poverty" analysis is like the Human Development Indicators or "basic needs" or other short-cuts that cannot be grounded in economics but which may (or may not) be useful on pragmatic or political grounds or may be grounded in other coherent approaches to assessing social objectives. That is, in judging objectives one cannot say approaches are "wrong" as many approaches to setting social objectives merit consideration in any national or international conversation about objectives. However, no one should be misled into believing that because poverty analysis is arcane and technical and uses economic data and some terminology from economics that it either poverty analysis itself or a low poverty line have any grounding in economics or represents a consensus among economists ${ }^{40}$. Moreover, since the proponents of low poverty lines are advocating a radical shift (and the lower the poverty line the more radical) in the way welfare economics is done and they should be more explicit why economics is wrong and how exactly the new poverty analysis is grounded ${ }^{41}$.

\section{Appendix 3: Does the concept of "the poor" have content in poor countries?}

What does it mean to set a standard for income poverty so low that income poverty is only 12.5 percent in Cote d'Iviore and only 31.5 percent in Ethiopia? It means that in most developing countries "the poor" are in fact exactly like the non-poor (but perhaps not like "the rich"). This is true in two senses, which by now have been well documented.

First, if one draws the "poverty line" through the thick part of the income distribution then "the poor" have essentially the same income as the poor. For instance, in Indonesia according to

\footnotetext{
${ }^{40}$ While there are an increasing number of economists who write about poverty, this is not because they believe that poverty is well-founded in standard welfare economics but rather because since other people are interested they are contributing to an on-going discussion.

${ }^{41}$ The apparent--although I have never actually seen this argument made explicitly) rationale for putting zero weight in a social objective function is grounding the construction of a social objective in something like the approach proposed by the philosopher John Rawls who argued that his imagined social contract foundation to justices could justify a "lexicographic" social ordering in which only the well being of the worst off would count (or more explicitly that there was no trade-off between gains to anyone but the worst-off and others). But, while John Rawls work is a pioneering and deeply influential work it is not obvious that it is widely accepted - people do not behave as if their preferences are lexicographic, and no society in the world has ever behaved as if their social orderings were lexicographic. Moreover, it is not obvious that the "lexicographic" nature of the resulting social preferences is robust to different, and reasonable, assumptions about risk aversion. Finally, even if one agrees that all economics should change to reflect John Rawls and even if one agrees that, in principle, the social welfare ordering should have the property that above some line increases in well-being should not be traded off against increases for those below that line, this still comes back to the question of "what line?" I am willing to accept a poverty line approach if one uses a line that is consistent with reality and not based on the assumption that gains to a person that push her above consuming one (or two) dollar a day should count zero.
} 
the WDR $2000 / 0115.2 \%$ were poor by $1 \$ /$ day but $66.1 \%$ were poor by the $2 \$ /$ day standard. So 50 percent of the population is separated by less than one dollar a day. How different are the "poor" from the "non-poor" in this situation? The consumption of one soft drink a day (I drink a 20 oz Diet Coke costing \$1.25 every day) would move a household from being in the worst category of poverty to out of poverty and well above the median. This is just a simple mathematical fact - near the mode of an income distribution the change in percentiles requires much smaller absolute changes that an equivalent change in percentiles at high levels of the distribution (so the absolute income gap separating the $30^{\text {th }}$ and $35^{\text {th }}$ percentiles is a tiny fraction of that separating the $90^{\text {th }}$ and $95^{\text {th }}$ percentiles. In fact, F. Scott Fitzgerald had it right and the low poverty line analysis gets it wrong-it is the rich that are different.

This can be seen in physical indicators of well being, like infant mortality rates. Comparing across asset index quintiles one sees that in the poorest countries the big improvements often don't occur until well up into the income distribution so that the "poor" and "non-poor" are substantially alike while the rich are different (although again, even "the rich" has indicators vastly worse than "the poor" in industrialized countries).

\begin{tabular}{|c|c|c|c|c|c|c|}
\hline \multicolumn{7}{|c|}{$\begin{array}{l}\text { Appendix table 3.1: Changes in physical indicators of well-being } \\
\text { are often relatively small across quintiles of assets until the highest } \\
\text { quintiles - in part because differences in income are absolutely } \\
\text { small }\end{array}$} \\
\hline & & QI & QII & QIII & QIV & QV \\
\hline \multirow[t]{4}{*}{ Nepal } & IMR & 96.3 & 107.2 & 103.6 & 84.7 & 63.9 \\
\hline & Change & & 10.9 & -3.6 & -18.9 & -20.8 \\
\hline & Stunting & 59 & 51.7 & 48.1 & 43 & 31.8 \\
\hline & Change & & -7.3 & -3.6 & -5.1 & -11.2 \\
\hline \multirow[t]{4}{*}{ Nigeria } & IMR & 102.2 & 102.3 & 93.1 & 85.8 & 68.6 \\
\hline & Change & & 0.1 & -9.2 & -7.3 & -17.2 \\
\hline & Stunting & 48.5 & 45.3 & 47.2 & 40.5 & 32.1 \\
\hline & Change & & -3.2 & 1.9 & -6.7 & -8.4 \\
\hline \multirow[t]{4}{*}{ Ghana } & IMR & 77.8 & 93.6 & 83.8 & 63.9 & 45.8 \\
\hline & Change & & 15.8 & -9.8 & -19.9 & -18.1 \\
\hline & Stunting & 35.3 & 29.1 & 27.9 & 22.8 & 12.6 \\
\hline & Change & & -6.2 & -1.2 & -5.1 & -10.2 \\
\hline
\end{tabular}

Second, households are not "poor" or "non-poor" in the sense that households are "rural residents" or "male headed" or "have two children." That is, now that panel information is available it has been clearly seen that, for the most part, it is not the same households who are poor period after period. Rather even if the poverty rate measured at any point in time is relatively low (say, 20 percent) when measured repeatedly the data will show enormous churning as people move in and out of episodes of poverty. The phrase "poor households" is probably no longer even useful terminology, something description like "households in an episode of measured poverty" or "households experiencing poverty" or some such more realistically conveys the reality that, while there are some households that are chronically poor and some households who are never poor, many households move in and out of poverty. 
This is a useful corrective to the view, coming principally from developing countries that somehow the poor are different - that poverty is strongly associated with identifiable characteristics of social disadvantage (like discriminated races or ethnicities, physical or mental disabilities, low education) and that there is a set of "hard core" poor who remain poor for substantial periods. While there are certainly such groups in developing countries - the "poorest of the poor"this is not how to characterize poverty in countries where a large bulk of the population live in conditions of material deprivation much worse than that of the poor in rich countries. 


\section{Center for Global Development Working Papers}

No. 1, January 2002

No. 2, January 2002

No. 3, February 2002

No. 4, March 2002

No. 5, April 2002

No. 6, May 2002

No. 7, May 2002

No. 8, June 2002

No. 9, August 2002

No. 10, Sept. 2002

No. 11, October 2002

No. 12, October 2002

No. 13, October 2002

No. 14, October 2002

No. 15, October 2002

No. 16, October 2002
Inequality Does Cause Underdevelopment: New Evidence, William Easterly

HIV/AIDS and the Accumulation and Utilization of Human Capital in Africa, Amar Hamoudi and Nancy Birdsall

External Advisors and Privatization in Transition Economies, John Nellis

The Cartel of Good Intentions: Bureaucracy versus Markets in Foreign Aid, William Easterly

Intellectual Property and the Availability of Pharmaceuticals in Developing Countries, Jean O. Lanjouw

Winners and Losers: Assessing the distributional impacts of privatization, John Nellis and Nancy Birdsall

Commodity Dependence, Trade, and Growth: When 'Openness' is Not Enough, Nancy Birdsall and Amar Hamoudi.

Financial Crises and Poverty in Emerging Market Economies, William Cline

An Identity Crisis? Testing IMF Financial Programming, William Easterly

Solutions when the Solution is the Problem: Arraying the Disarray in Development, Lant Pritchett and Michael Woolcock

What did structural adjustment adjust? The association of policies and growth with repeated IMF and World Bank adjustment loans, William Easterly

Asymmetric Globalization: Global Markets Require Good Global Politics, Nancy Birdsall

Low Investment is not the Constraint on African Development, Shantayanan Devarajan, William Easterly, Howard Pack

An Index of Industrial Country Trade Policy toward Developing Countries, William R. Cline

Tropics, Germs, and Crops: How Endowments Influence Economic Development, William Easterly and Ross Levine

Do As I Say Not As I Do: A Critique Of G-7 Proposals On Reforming The $M D B s$, Devesh Kapur 
No. 17, October 2002

Policy Selectivity Foregone: Debt and Donor Behavior in Africa, Nancy Birdsall, Stijn Claessens and Ishac Diwan

No. 18, Nov. 2002

Private Sector Involvement in Financial Crisis Resolution: Definition, Measurement, and Implementation, William R. Cline

No. 19, Dec. 2002

Do Rich Countries Invest Less in Poor Countries Than the Poor Countries Themselves?, Michael A. Clemens

No. 20, December 2002

World Bank capital neither complements nor substitutes for private capital, Michael A. Clemens

No. 21, December 2002 From Social Policy to an Open-Economy Social Contract in Latin America, Nancy Birdsall

No. 22, January 2003

Global Economic Governance and Representation of Developing Countries: Some Issues and the IDB Example, Nancy Birdsall

No. 23, February 2003 The Millennium Challenge Account: How much is too much, how long is long enough?, Michael A. Clemens and Steve Radelet

No. 24, February 2003

Bootstraps Not Band-Aids: Poverty, Equity and Social Policy in Latin America, Nancy Birdsall and Miguel Szekely

No. 25, February 2003 Privatization in Africa: What has happened? What is to be done?, John Nellis

No. 26, March 2003

New Data, New Doubts: Revisiting “Aid, Policies, and Growth”, William Easterly, Ross Levine, David Roodman

No. 27, May 2003

National Policies and Economic Growth: A Reappraisal, William Easterly

No. 28, July 2003

Financing Pharmaceutical Innovation: How Much Should Poor Countries Contribute?, William Jack and Jean O. Lanjouw

No. 29, April 2003

Economic Policy and Wage Differentials in Latin America, Jere R. Behrman, Nancy Birdsall and Miguel Székely

No. 30, July 2003 The Surprise Party: An Analysis of US ODA Flows to Africa, Markus P. Goldstein and Todd J. Moss

No. 31, August $2003 \quad$ Privatization in Latin America, John Nellis

No. 32, September 2003 The Anarchy of Numbers: Aid, Development, and Cross-country Empirics, David Roodman 